\title{
DEL ALFAQUÍ SABIO A LOS SEUDO-OBISPOS: UNA PARTICULARIDAD ICONOGRÁFICA GÓTICA
}

Joaquín YARZA LUACES

Universidad de Autónoma de Barcelona

En su "Vida de San Millán de la Cogolla", Gonzalo de Berceo cuenta la aparición milagrosa del santo acompañado por el apóstol Santiago ayudando a los cristianos en una crucial batalla. La batalla, que viene precedida de diversos signos que son previamente interpretados por los sabios musulmanes, concluye con el triunfo cristiano. Los vencidos lo pierden todo. Entre otras cosas, dice:

"perdieron su obispo, persona muy onrrada, perdieron el libro en qe era sue leï debuxada" ${ }^{1}$.

Es de toda evidencia que el libro es el Corán, pero, ¿quién es esa persona a la que llama obispo? Quizá Gonzalo de Berceo no estuvo aquí muy atento a su fuente principal y alude a un obispo en ningún momento anterior mencionado, pero de lo que no hay duda es de que detrás de tal personaje se esconde un sabio y santo musulmán, alguna suerte de alfaqur. ¿Cómo se justifica que lo llame obispo? Creo que sin duda porque sigue un procedimiento muy medieval, presente en textos e imágenes. Se trata de trasponer a un lenguaje escrito o plástico inteligible y medieval un concepto de otra procedencia. A Alejandro

${ }^{1}$ Utilizo siempre la edición de Brian Dutton, La "Vida de San Millán de la Cogolla" de Gonzalo de Berceo, Londres, 1967, p. 153, correspondiente a la estrofa 455 . 
Magno o a Julio César se les llama caballeros y, por la misma razón, a un sabio musulmán, obispo.

Muy probablemente, la fuente latina inmediata a la que recurrio había sido redactada poco antes por el monje Fernando, casi contemporáneo suyo. Estábamos en un momento muy especial del monasterio de San Millán de la Cogolla. Quizás hacía algún tiempo que el llamado Privilegio de los Votos no era cumplido con normalidad. Una tradición decía que en una antigua batalla entre cristianos y musulmanes, Santiago y San Millán habran acudido con excelente resultado en auxilio de los primeros. A consecuencia de ello se había instituido la costumbre de un pago al monasterio al que se veran obligados villas y lugares muy variados. En el entorno de 1200 tales pagos se demoraban. Fernando redacta un documento falso donde se cuenta todo con cierto detalle y Gonzalo de Berceo apuntala este intento del monasterio de obtener semejante beneficios concediendo un espacio grande en su obra al supuesto hecho milagroso ${ }^{2}$. El texto de Fernando se redacta en latín. En la parte correspondiente se dice: "Librum sue perdicionis ac pontificum caput sui erroris cum omnibus tentoriis suis acepimus" ${ }^{\prime 3}$.

El texto latino utiliza la palabra "pontificum" para designar al sabio musulmán. Aunque se trata de una palabra destinada a dar nombre a un cargo religioso romano pagano, los cristianos habían comenzado a aplicarla a los obispos desde tiempos muy antiguos. Es el caso de Sidonio Apolinar en sus "Carmina" $(16,6)$. Por ello es normal que Berceo trasladara el vocablo al castellano como "obispo".

Por otra parte, hay que tener en cuenta que la versión más amplia de la historia de la presencia milagrosa de los santos se redactó en romance, seguramente en La Rioja y en el siglo XIII. Es también la más clara y la que despeja toda duda respecto al "obispo" del poeta: en tiempos del conde Fernán González aparecen unas señales en el cielo

${ }^{2}$ No es cuestión aquí de discutir este problema. Por ello remitimos especialmente a la citada obra de B. Dutton, donde se defiende la tesis de que la elaboración de la biografía de Berceo no fue tan ingenua y devota como la historiografía clásica suponía, sino que existieron otras intenciones, como la propagandística. Su convincente opinión viene bien argumentada y acompañada de la transcripción del texto latino del monje Fernando y su traducción romance.

${ }^{3}$ Dutton, Op. cit., p. 229. También p. 3. 
que provocan temor entre cristianos y musulmanes. Abderramán, por este motivo $y$ otros que implican ya unas primeras actuaciones cristianas, quiere saber su significado. Se le aconseja que consulte a Alfarami, un sabio que vive en Mecha. Efectivamente, éste da una prolija explicación, que luego se demostrará engañosa. Pero se celebra la batalla famosa con el resultado que conocemos. Como consecuencia: "Ally fue presso el rey Abderramán e fue presso su sabio que los aduxo a merçed e fueron todos descabeçados"4.

En definitiva, que se quiso involucrar en la derrota musulmana no sólo al poder civil, sino también a gentes que en cierta medida estarían vinculados al mundo religioso, y a la hora de dar un nombre a este sabio y pro personaje se le llamó "pontificum" u "obispo". Es el caso más antiguo que conozco en lengua castellana, pero en modo alguno el único. Nos encontramos ante una situación muy característica de la Edad Media. Para los cristianos de entonces, y me refiero a los últimos siglos medievales, la autoridad eclesiástica por excelencia es el obispo. Por tanto, cuando se presenta un caso en el que se menciona a alguín alto dignatario religioso judío, islámico o gentil, es probable que se califique de "obispo". No de otro modo se comportan los artistas cuando se repiten estas circunstancias en pinturas, miniaturas $o$ esculturas.

Y como muestra más llamativa, la que elegimos en primer lugar. Pocas imágenes de la pintura gótica hispana causan mayor perplejidad que una tabla del retablo de Santa Clara de Vic (M. Diocesano, Vic) (fig. 1), debido a Lluis Borrassà, donde los apóstoles Judas Tadeo y Simón son atacados por seis obispos que les cortan la cabeza. Según un procedimiento caro a la Edad Media, en el mismo escenario se han sucedido dos hechos. Estamos en Samir o Mair, una ciudad de Oriente del dominio de un supuesto rey de Babilonia. Allí, dos magos habían conseguido indisponer contra los apóstoles Simón y Judas Tadeo a los sacerdotes paganos que atendian un templo dedicado al sol. Llevados al santuario en el que se levantaban las estatuas de varios dioses, de los que aquí se ven al menos tres, ponen de manifiesto que están habitadas por demonios. Consiguen expulsarlos y son los mismos seres malignos,

${ }^{4}$ Dutton, Op. cit., pp. 12-16. 
volando en la pintura, los que destruyen esos iconos que ocupaban. El hecho es contemplado seguramente por los dos magos y un pontifice estupefacto. La acción despierta la ira violenta de los setenta pontífices que se arrojan contra los apóstoles y los matan.

Se trata por tanto de nuevos religiosos paganos a los que el pintor ha convertido en obispos ${ }^{5}$. La historia se cuenta en la "Leyenda Dorada" de Jacopo da Varazze con todo lujo de detalles. Pero en una traducción libre hecha en Cataluña ya a fines del siglo XIll o poco después, se alude a estos sacerdotes siempre con el nombre de "bispes". La peripecia de los apostoles en Babilonia había comenzado antes y ya habían debido enfrentarse a otros personajes con los que acabarán en buenas relaciones. Igualmente en este caso estos individuos reciben el nombre de "bispes", obispos. Tal vez no fue ésta la fuente literaria ${ }^{6}$ a la que recurrio Borrassà, porque en ella se habla de dos demonios y dos estatuas, mientras aquí hay tres, pero el hecho es el mismo. Para hacerse entender, tanto los autores del texto, como el pintor, convirtieron a los sacerdotes paganos en obispos. $Y$ hay que destacar esto, porque podía haberse tratado de meros sacerdotes, mientras por el contrario se ha elegido un grado alto en la jerarquía eclesiástica?

${ }^{5}$ He tocado brevemente el tema en relación a las costumbres medievales y por el prestigio que adquiere la figura del obispo entonces en J. Yarza Luaces, La imatge del bisbe en el gòtic català, en Thesaurus. L'art als Bisbats de Catalunva 1000-1800, Barcelona, 1985, p. 134.

${ }^{6}$ He utilizado la edición reciente de Ch. S. Maneikis, E. J. Neugaard, Vides de Sants Rosselloneses, Barcelona, 1977, III, pp. 374-375. La historia anterior en pp. 372-373. La redacción es más sucinta que en la recientemente traducida al castellano como Santiago de la Voragine, La Leyenda Dorada, Madrid, 1982, II, pp. 686-687. El original utilizado era el latín y, a juzgar por el uso de la palabra "pontífice", "pontifex" debía ser el nombre con que se designaba a estos representantes del paganismo. Es asimismo muy interesante la presencia del pilar sobre el que se alzan las tres estatuas de dioses, según otro procedimiento muy querido en el gótico y que merecería un análisis más detallado. Envío, en todo caso, al reciente, documentado, discutido y discutible estudio de $\mathrm{M}$. Camille, The gothic idol, Cambridge, 1989, con amplia bibliografía y escasa atención a lo hispano.

${ }^{7}$ Aunque en el texto citado se llaman obispos a los sacerdotes de este templo, no siempre sucede así. Por ejemplo, un predicador popular tan carismático como San Vicente Ferrer, que actuaba por los mismos años en que se pintaba el retablo 
De todos modos hay que indicar que, si bien no estamos ante un "unicum", no es muy frecuente este tipo de imágenes. Recordaré, no obstante, en la misma Cataluña y por los mismos años, un retablo de Joan Mates conservado fragmentariamente y dedicado a los santos Juanes. El sumo pontifice de un templo de Diana propone al Evangelista beber una copa envenenada, para que muera o se salve, según reciba o no la ayuda de Dios ${ }^{8}$. En la pintura el pontífice es un obispo. En la versión catalana de la Leyenda Dorada de nuevo se utiliza el término "bisbe", obispo, cada vez que se menciona a este personaje del que se indica que se llamaba Aristo o Aristodemo?.

En el ámbito de la Corona de Castilla las cosas no suceden de otro modo, tanto en los textos como en las imágenes. Y ya no en obras religiosas, sino incluso en algunas profanas. El "Victorial" o Crónica de Pero Niño, de Gutierre Díez de Games, es un libro notable por muchas razones, entre ellas por la interpolación, al hilo narrativo de los hechos del protagonista, de historias de diversa procedencia. Entre ellas el relato de Dorotea, supuesta mujer de Bruto, a su vez héroe de la primitiva Inglaterra. Cuando recibe la propuesta de matrimonio, Dorotea reúne a sus consejeros quienes hablan uno tras otro. Entre ellos se encuentra "Panteo, el ovispo". En su discurso dice: "yo sacreficaré a los dioses", lo que indica que es sacerdote pagano de su tierra. Al acabar de hablar se dice: "Calló el ovispo"10.

De igual manera, el Maestro de Burgos o de Los Balbases presenta en su retablo de Santo Tomás, para la iglesia de esa advocación en

de Borrassà, dedica un amplio sermón a ambos apóstoles en el que se ve que sigue muy directamente la Leyenda Dorada. Al llegar al acto final objeto de nuestra pintura, califica de "sacerdots" a los setenta encargados del templo del "sol e la lluna". Por cierto que, mientras la Leyenda catalana dice que estos individuos destrozaron ("espeseyeren") a los apóstoles, San Vicente afirma que "a colp de coltell e de spasa mataren-los", acercándose más a la pintura (Sant Vicent Ferrer, Sermons, IV, al cuidado de G. Schib, Barcelona, 1977, sermón 119, pp. 174-175).

${ }^{8}$ La tabla pertenece a una colección particular de Barcelona. Ver, J. Gudiol, S. Alcolea, Pintura gótica catalana, Barcelona, 1986, catálogo n²34, fig. 429.

${ }^{9}$ Maneikis y Neugaard, $O p$. cit., II, p. 92.

${ }^{10}$ Gutierre Díez de Games, El Victorial. Crónica de Don Pero Niño. Conde de Buelna, ed. y est. de J. Mata Carriazo, Madrid, 1940, pp. 149-150, cap. LVI. 
Covarrubias (Burgos), la escena del sacrificio del apóstol a manos de un obispo (Museo colegiata de Covarrubias) (fig.2). Los hechos ofrecen un paralelo perfecto con el relato de la vida de Simón y Judas Tadeo. El apóstol, que está en la India, hace que el demonio que lo habita funda el ídolo del dios local de modo que éste caiga. El pontífice máximo enfurecido corta la cabeza de Tomás con una espada. Sólo parte de esto se ve en la tabla, porque está muy lastimada y debe faltar la zona superior, ${ }^{11}$ pero es perfectamente visible la mitra sobre la cabeza del pontífice que todavía lleva en la mano la espada asesina.

Naturalmente, el ámbito en el que me estoy moviendo es el hispano, pero no debe olvidarse que algo semejante ha de suceder en otros lugares de Europa. He de adelantar que ciertas particularidades a las que más adelante voy a referirme, se producen con normalidad sólo en lugares muy concretos, incluso de la geograffa hispana. Pero no con todo sucede así. A título de ejemplo quiero mencionar un caso que resulta impactante. Alejandro Magno disfrutó de una popularidad sin paralelo con cualquiera de los héroes de la antigüedad, tanto judíos como paganos, en textos y en imágenes. Narraciones extravagantes le hacían viajar a la India y encontrar a seres y plantas extraordinarios, como el Árbol del Sol y la Luna, contado ya en la "Historia de preliis", pero recogido en otras posteriores. Así, Johan Hartlieb, un alemán, hace una versión en su lengua hacia 1444 , que se ilumina con alguna ilustración. En la correspondiente a la visita a dicho árbol (fol. 283v.) (fig.3) Este le es mostrado por un sacerdote que se cuida de lo que afecta a su culto, mientras se dirige al rey macedonio para decirle cómo debe comportarse ante él. Se encuentra completamente desnudo, cubierto de pelo, casi como un salvaje, pero sobre la cabeza lleva la mitra que, prestada del obispo, le identifica como sacerdote importante ${ }^{12}$.

${ }^{11}$ J. Yarza Luaces, "El Retablo de Santa María del Castillo (Frómista). Problemas de la pintura en Palencia a fines del siglo XV", en Jornadas sobre el gótico en la provincia de Palencia, Palencia, 1988, pp. 109-110; P. Silva Maroto, Pintura hispanoflamenca castellana: Burgos y Palencia, s.1., 1990, II, n 51, p. 618.

${ }^{12}$ Se conserva en Nueva York, J. P. Morgan Library, Ms. 782, y se supone copiado en Alemania hacia 1455-1465. EI aspecto selvático del sacerdote le hizo 
Pocos años después se hacía una nueva copia del texto, ya impresa y con algunas xilografías, repitiéndose invertida la composición, que incluye, por tanto, el desnudo sacerdote, que lleva como única prenda de vestir la mitra identificadora ${ }^{13}$.

El ámbito de estos falsos obispos es mayor de lo que se podría creer. No son únicamente los pontffices paganos quienes se convierten en falsos obispos. Incluso los dioses Júpiter y Mercurio pueden llevar tiara. Se ha llamado la atención sobre el hecho de que Miguel Scoto, el famoso erudito y astrólogo de Federico II, dio una versión astrológica de los dioses planetarios muy singular, con antecedentes islámicos que a su vez se retrotraen a la antigüedad clásica y aun mesopotámica. Así, Mercurio o Hermes se identifica con Thot, la divinidad egipcia relacionada con la erudición, sobre todo a partir de los escritos del llamado Hermes Trismegisto. En Scoto, Mercurio es un hombre de letras, un sabio escriba. Debido a ello, cuando alguna de estas obras se ilustran con miniaturas se elige para el papel del dios al que mejor representa este carácter intelectual: un obispo. Así lo encontramos en varios manuscritos, como en un Miguel Scotus, "Introductorium magnum" (Munich, Staatsbibliothek, Cod. lat., 10268, fol. 85), del siglo $\mathrm{XIV}^{14}$, en pie, vestido con ropas sacerdotales, llevando báculo y coronando su cabeza una mitra, mientras una inscripción no permite dudas sobre su identidad (fig.4). Aunque sea menos normal, el mismo Júpiter, hecho clérigo en más de una ocasión, como en los relieves del "campanile" de la catedral de Florencia, también puede ser obispo. De este modo lo encontramos en otro códice del mismo autor, mucho más torpe de ejecución y en que de nuevo es prelado asimismo Mercurio. Es un personaje algo ambiguo, pero sin duda cubre parte de su cabeza con una mitra (Viena, Biblioteca Nacional, ms. 2378, fol. 12v.) ${ }^{15}$.

figurar en una exposición dedicada al salvaje medieval (Th. Husband, The Wild Man. Medieval myth and symbolism, Nueva York, 1981, $\mathrm{n}^{\circ} 6, \mathrm{pp}$. 54-56.).

${ }^{13}$ Husband, Op. cit., $\mathrm{n}^{\circ}$ 7, fol. 259. Se trata de una edición hecha en Augsburgo en 1473. Ver fig. 28 de dicha publicación.

${ }^{14} \mathrm{~F}$. Saxl, La vida de las imágenes, singularmente El renacimiento de la astrologia de finales de la antigüedad, Madrid, 1989, pp. 74 y ss., fig. 44.

15 J. Seznec, La survivance des diewx antiques, París, 1980, pp. 143 y ss., lám 61. Son ambos autores quienes suponen que el modelo no es de dioses sin 
Si el alfaqứ musulmán, el sacerdote pagano y aún los dioses grecorromanos han merecido este tratamiento de obispos, parece normal que aún se vieran más afectados por el uso de tal regla icónica medieval los sacerdotes y aun profetas de la ley judaica. Y asi es en realidad. Se ha sugerido que las razones para ello eran distintas, aunque salvo excepciones entiendo que la principal es la mencionada, como trataremos de ver ${ }^{16}$. He elegido dos textos catalanes para presentar a continuación y me referiré a otro castellano donde de nuevo se mencionan figuras del judaísmo con el apelativo de "obispos", aunque es seguro que una amplia búsqueda en este terreno, y citaré algún ejemplo más, dará una cosecha más abundante que tan sólo reforzaría el hecho, sin producir cambios, aunque es cierto que no todos los autores han recurrido a tal procedimiento ${ }^{17}$. Por ejemplo, "a priori" se hubiera dicho que un predicador popular del género de San Vicente Ferrer sería aficionado a recurrir a tal vocablo para hacerse entender más inmediatamente de su auditorio. Sin embargo, de un repaso somero de su sermonario se deduce que tal vez huyera a propósito de lo que en ese caso debió juzgar motivo de error y no de claridad ${ }^{18}$.

más, sino que proceden de la astrología antigua a través de los árabes, aunque Scoto y sus ilustradores muestran cierta independencia respecto a los supuestos modelos.

${ }^{16}$ En cierta manera, el análisis de algunos aspectos de la imagen del judío como obispo, en Antiguo y Nuevo Testamento, es abordado por R. Mellinkoff, Christian and Jewish mitras: a paradox, en Florilegium in honorem Carl Nordenfalk, Estocolmo, 1987, pp. 145-158, aunque la autora centra el tema sólo en ciertos aspectos relativos a la forma de la mitra en relación a los cuernos de Moisés, a quien estudió en otra ocasión. Agradezco a Francesca Español el haberme llamado la atención sobre este estudio.

${ }^{17}$ Esta presencia bajo "disfraz" no implica ningún juicio de valor sobre ellos. Quizás por eso ni aún ha sido señalada esta clase de imágenes por B. Blumenkranz, Le juif médiéval au miroir de l'art chrétien, París, 1966, quizás más preocupado por la visión negativa desde la perspectiva cristiana.

${ }^{18}$ No he leido detenidamente todos los sermones, pero me he fijado especialmente en aquéllos sobre la vida de Cristo que suelen utilizar pintores y literatos para figuras y nombres episcopales, comprobando que en Vicente Ferrer no se encuentran. Ver, Sant Vicent Ferrer, Sermons, ed. Sanchis Sivera y G. Schib, Barcelona, 1932 (1971)-1988, 6 vols. 
Por el contrario, en una pequeña obra, especie de sermón alegórico, como ha sido llamado, "La Passió de Jesucrist" o "Les Corts generals de Jerusalem", de fines del siglo XIV o inicios del siguiente, se insiste en recurrir al término. Después del prendimiento, Jesús es llevado a casa de Anás, sumo sacerdote. Se dice entonces: "Estant Jesuchrist devant la presència del bisbe" ${ }^{19}$. Inmediatamente se comenta que muchos gritaban contra él "a la porta del bisbe". La Virgen se queja de la situación como modo de concluir el relato, lo que sirve para una última indicación, aún más precisa, en la que se asegura que esto ocurrió "en casa de Anna, bisbe" ${ }^{20}$. Por el contrario, Caifás es calificado únicamente de "príncep dels sacerdots"21.

El dominico italiano Domenico Cavalca escribe a inicios del siglo XIV un "Specchio di Croce" que en el siglo XV es traducido al catalán por el benedictino Pere Busquets ${ }^{22}$. Al contrario que en el sermón antes mencionado ya el religioso catalán llama obispo a Caifás ("la casa de Cayphàs, bisbe" ${ }^{23}$. Pero es más significativo, por el paralelo que luego comprobaremos en la pintura, que vuelva a concederse esa denominación a los "príncipes de los sacerdotes" que asisten a la muerte de Jesús en la cruz. Mateo, Marcos y Lucas los mencionan. Cavalca alude a Mateo (XXVII, 41 y-ss.) en ese momento en que tales individuos ("principes sacerdotum") le insultan, traduciendo Busquets: "com diu sant Matheu, que los bisbes e sacerdots, menant lurs caps, lo escarnien"24.

${ }^{19}$ Les Corts generals de Jerusalem, ed. Mateu Rodrigo Lizondo, Barcelona, 1985, p. 53.

${ }^{20}$ Hay otros momentos de la visita en que se usa la misma palabra. Cuando Pedro niega a Jesús, "un escuder del bisbe" se dirige a él (p. 54). De igual modo, inmediatamente después, se cita "lo bisbe Anna" (p. 55). Ante una respuesta de Jesús a Anás, Malco le da una gran bofetada diciendo al mismo tiempo: "Axí respons al bisbe tu?" (p. 56).

${ }^{21}$ Op. cit., p. 56.

${ }^{22}$ Domenico Cavalca, Mirall de la Creu, versió catalana del segle XV feta per Pere Busquets, ed. A. Gallina, Barcelona, 1967, 2 vols. Agradezco a F. Español que me haya llamado la atención sobre esta obra.

${ }^{23}$ Op. cit., vol. I, cap. XIX, p. 138.

${ }^{24}$ Op. cit., I, cap. XIX, pp. 142-143. Asimismo, cuando reflexiona sobre la 
En una traducción en romance castellano del Evangelio de San Mateo de h. 1254-1270, se introduce la palabra obispo, para designar a Caifás: "Ellos prisieron a Ihesu Christo, e levaron le a Cayphas, el obispo" $^{25}$. Esto es anterior a las obras catalanas citadas. En otros lugares de Europa se hacía lo mismo, como en las indicaciones generales sobre el modo de vestir de los actores en la representación del "Ludus Coventriae" inglés: "Here xal annas shewyn hym-self in his stage be-seyn after a busshop of the hoold law... and a mytere on his hed after the hoold law" ("Aqui Annas se mostrará vestido como un obispo de la Antigua Ley... y una mitra en su cabeza según la costumbre de la Antigua Ley") ${ }^{26}$.

Por tanto parece que hay dos momentos especiales de la pasión de Jesús en la que importantes religiosos judíos son calificados de obispos. Por un lado, en los primeros momentos, cuando es conducido ante Caifás o Anás. En segundo lugar, cuando está crucificado y recibe los insultos de variadas gentes entre las que se encuentran los príncipes de los sacerdotes. Existen en la infancia de Jesús dos ocasiones más en las que podría requerirse la presencia de un alto sacerdote de la ley mosaica. Se trata de su circuncisión y de la purificación de María. Únicamente los menciona San Lucas y tan sólo en el segundo caso presenta al anciano Simeón, no tanto como príncipe de los sacerdotes, sino como hombre justo y temeroso de Dios ("homo justus et timora-

clase de personas que le injurian, cita a los hombres viles y, entre ellos, a "los rapaços dels bisbes", uno de los cuales es el de la bofetada antes mencionada ("un dels ministres del bisbe") (Op. cit., cap. XXI, pp. 151-152).

${ }^{25}$ Se encuentra en un manuscrito (ms. 1116) conservado en la biblioteca de El Escorial, editado por Thomas Montgomery, Madrid, 1962, que cito según Martín Alonso, Diccionario medieval español, Salamanca, 1986, II, p. 1442. Tampoco es frase común en la correspondiente literatura castellana. Así, Diego de San Pedro en su famosa "Passión trobada", se limita a nombrar a Anás y Caifás, sin añadir nada sobre su profesión (Diego de San Pedro, Obras completas. III, ed. D. Severin, K. Whinnom, Madrid, 1979, Passión Trobada, 66 y ss., pp. 137 y ss.). Curiosamente, cuando es el servidor de Anás el que habla abofeteando a Jesús, lo hace así:" ¿Y tú has de ser osado / al obispo assí hablar?" (p. 138). ¿Sería factible deducir de ello que de este modo se distingue el discurso culto del poeta de aquel popular del servidor airado?

${ }^{26}$ Mellinkoff, Op. cit., p.155, según la edición de K. S. Block, de Ludus Coventriae, Londres, 1922, p. 230. 
tus") (Lucas, II, 25). Naturalmente, como veremos, a esto no se deben sino añadir los episodios apócrifos de María, antes del nacimiento de su Hijo, donde se mencionan altos cargos del templo de Israel. Y estamos por ahora tan sólo hablando de la Nueva Ley o los finales de la Antigua.

Los artistas y sus mentores utilizaron estos datos y algún otro de forma muy desigual, tanto en lo que se refiere a las historias en que presentan obispos, como en los lugares. Así nos encontramos que es en relación con narraciones apócrifas incorporadas a la "Leyenda Dorada" donde se descubren las primeras posibilidades de imágenes. Comencemos por los momentos primeros, anteriores a la vida de Cristo. En la obra de Jacopo de Varazze se explica el nacimiento de María y su entrega al servicio del templo. Al alcanzar la edad núbil, sus compañeras salen de allí para casarse, pero se plantea la especial situación de quien será madre de Jesús. La resuelve el pontifice encargado, a quien en la versión catalana se le llama repetidas veces "bispe" o "bisbe"27. Pero cuando llega la hora de los desposorios nadie explica si los ofició este pontífice u "obispo" u otra persona.

Sin embargo, no es raro encontrar a una persona de estas características en la pintura. Por ejemplo, en el retablo de la Pentecostés de San Llorenç de Morunys, atribuido a Pere Serra, la lectura iconográfica comienza con unos Desposorios de María y José presididos por un obispo mitrado, sin duda el "bisbe" o "pontífice" que llevó a cabo el asunto de la elección de esposo ${ }^{28}$. Casi por los mismos años se terminaba el retablo de la Virgen y San Jorge para el monasterio franciscano de Vilafranca del Penedes, atribuido a Lluis Borrassà, donde de modo coherente una parte de la vida de María concluye con su matrimonio con José, de nuevo preparado por un personaje mitrado.

${ }^{27}$ Vides de Sants Rosselloneses, III, p. 261. Una vez más conviene recordar que únicamente ciertos textos presentan esta denominación. Recuérdese, por ejemplo, a Sor Isabel de Villena, Vita Christi, Valencia, 1497 (ed. facsímil, Valencia, 1980), cap. IX, pp. XV y ss., quien llama siempre a este importante cargo del templo, "lo grant sacerdot".

${ }^{28} \mathrm{~J}$. Gudiol y S. Alcolea, Pintura gótica catalana, Barcelona, 1986, n ${ }^{\circ} 133$, p. 58 , fig. 269 . 
En la pintura catalana no existen muchos retablos que recojan esta historia apócrifa, por lo que tampoco se repiten mucho estas visiones. En la castellana es más frecuente, aunque rara es la situación en que se recurra al obispo mitrado para pintar o esculpir al gran sacerdote de la antigua ley. Con todo hay casos bastante excepcionales en los que surge por vez primera el pontífice, que es quien recibe a la Virgen en el templo, convertido en un solemne obispo, como se ve en el retablo mayor de la Virgen de la Cartuja del Paular (Madrid) (fig.5), de fechas muy avanzadas, propias del último gótico. Es uno de los relieves compositivamente más ambiciosos. A la Virgen niña acompañan numerosas personas, además de sus padres, y en la parte alta de una construcción minuciosa y detallada se encuentra el destacado personaje. Ya en Aragón, entre los restos de murales de la iglesia de Santa María de Ipas (M. Diocesano de Jaca) se incluyen unos curiosos Desposorios de José y María oficiados por un obispo tocado con mitra, mientras la escena respira un aire profano y cortesano por la presencia de dos personajes a la derecha, vestidos a la moda del siglo $X^{29}$. También en el retablo pintado de Santa Ana de la iglesia de Tardienta (Huesca), hoy en el Museo Episcopal y capitular de Huesca, asoma un sumo sacerdote-obispo ${ }^{30}$. Debió ser bastante común este modo de ver las cosas en Aragón en el siglo XV, porque de nuevo se reitera el hecho en obras como el retablo de la Virgen (1465) de Nicolás Zahortiga en la colegiata de Borja, donde es un obispo quien recibe a María y el que realiza los desposorios posteriores ${ }^{31}$ (fig.8).

${ }^{29}$ M. C. Lacarra, Catedral y Museo Diocesano de Jaca (Musea Nostra), s.l., 1993, pp. 109-110, fig. 132.

${ }^{30}$ Obra atribuida en tiempos al Maestro de Riglos, hasta que F. Balaguer, Datos inéditos de arte aragonés, en Argensola, 6 (1951), pp. 56-58, descubrió los pagos a Bernat de Aras en nombre de Pedro de Zuera. Sin embargo, existen problemas estilísticos aún no bien aclarados (M. C. Lacarra, C. Morte, Catálogo del Museo Episcopal y Capitular de Huesca, Zaragoza, 1984, Pintura, n 7, pp. 75 y ss.).

${ }^{31}$ De antiguo considerado como obra de Jaime Lana, F. Oliván, Bonanat y Nicolás Zahortiga y la pintura del siglo XV. Estudio histórico-documental, Zaragoza, 1978, pp. 85 y ss., encontró un documento de pago que permite una atribución más adecuada al estilo. Ver también, F. Mañas, Pintura gótica aragonesa. Zaragoza, 1979, pp. 149 y ss. Existe en este retablo una verdadera 
Citaré igualmente los restos de otro posible retablo puesto bajo la autoría del anónimo pintor burgalés conocido como Maestro de Budapest. La tabla de los Desposorios se centra con un gran sacerdoteobispo (Barcelona, Museo catedral) ${ }^{32}$. Se ha querido buscar antecedentes compositivos a esta escena fuera del ámbito peninsular, ${ }^{33}$ citándose un manuscrito del primer tercio del siglo XV del taller del Maestro de las Horas de Rohan. Con él nos adentramos brevemente en lo europeo.

Tengo la impresión de que este tipo de imágenes es algo menos común en Francia, Países Bajos o Italia que en la Penf́nsula, mientras la riqueza figurativa de estos paises es mucho mayor que la nuestra. Sin embargo, ya he mencionado el manuscrito alemán con el sacerdote pagano completamente desnudo, pero con mitra. De todas maneras se impone una diferenciación clara por países. Es en Italia donde constituye una rareza, tampoco es común en los Países Bajos, mientras es mucho más frecuente en Francia, siendo probable que ciertos casos tengan allí su origen. Así en la menuda escena marginal del mencionado manuscrito francés (Cambridge, Fitzwilliam Museum, Ms. 62, fol. 29) de hacia 1417, procedente del taller del Maestro de Rohan, también es un obispo el oficiante. Añadamos el "Libro de Horas" del Maestro de la Leyenda Dorada de Munich, asimismo parisino, datado hacia 1425-1430 (Baltimore, Walters Art Gallery, Ms. W. 288, fol. 17), especialmente importante, porque utiliza estos signos distintivos en otras circunstancias $^{34}$. No quiere decir ello que la particularidad iconográfica sea exclusiva de la escuela parisina de entonces. Por ejemplo, el casi

obsesión por la imagen de los "obispos" judíos. Comienza por serlo quien expulsa a San Joaquín y Santa Ana del Templo a causa de su esterilidad. Lo vuelve a ser el que oficia la Circuncisión. Se detectan otras singularidades iconográficas ajenas a nuestro tema, como la presencia de la Virgen en la resurrección de su hijo, tema característicamente catalán adoptado por contaminación por un aragonés.

${ }^{32}$ Silva, Op. cit., I, pp. 335 y ss., fig. 68.

${ }^{33}$ Silva, Op. cit., pp. 336-337.

${ }^{34}$ Reproducidas todas sus imágenes mayores, en R. S. Wieck, The Book of Hours in medieval art and life, Londres, 1988, pl. 1-12. Respecto a las Horas anteriormente citadas, ver M. Meiss, French painting in the time of Jean de Berry. The Limbourgs and their contemporaries, Londres-Nueva York, 1974, fig. 863. 
contemporáneo Maestro de las Horas Bedford, en sus espléndidas "Horas" (Londres, British Library, Add. Ms. 18850, fol. 32) adorna la cabeza del sacerdote con un gran gorro, que no es una mitra. Y esto es lo más común, pero no excluye que en un momento $u$ otro cualquier artista recurra al cómodo procedimiento de identificación, como a principios del siglo XV en las "Grandes Horas" de Jean de Berry (París, Bib. Nat., Ms. Lat. 919, fol. 37), en un escenario arquitectónico que permite el despliegue de una gran muchedumbre ${ }^{35}$ (fig. 7). También años después el mismo Jean Fouquet en sus extraordinarias "Horas de Etienne Chevalier" (Chantilly, M. Condé), ofrece la imagen del gran sacerdote portador de mitra, aunque da la impresión de que la pieza de orfebrería que luce sobre el pecho alude a las doce piedras preciosas propias de los atributos del sumo sacerdote judio ${ }^{36}$. Poco antes, la Presentación de María en el Templo se despliega en las "Grandes Horas" de manera que todo se convierte en el escenario para un acto cristiano en el que la niña va coronada y es recibida tras el altar por un obispo con ropas de gran aparato, báculo y mitra (fol. 31) (fig. 8).

Si de lo francés pasamos a lo inglés, nos encontraremos ya al pontifice convertido en obispo en los Desposorios desde tiempos muy antiguos, como en las "Horas de William de Brailes" (Londres, British Library, MS. Add. 49999, fol. 10v.), pionera de esta clase de libros (c. 1240), en los maitines de la Virgen (fol. 10v.), aunque ya parecía verse vestido de la misma manera poco antes en la Presentación de María en el templo (fol.9) ${ }^{37}$. Es muy altamente probable que la

${ }^{35}$ M. Thomas, Les Grandes Heures de Jean de France, duc de Berry, París, 1971, pl. 55.

${ }^{36}$ Probablemente el estudio más amplio sobre la infancia de la Virgen en Oriente y Occidente sea el de J. Lafontaine-Dosogne, Iconographie de la Vierge dans l'empire byzantin et en Occident, Bruselas, 1964-1965, 2 vols. No presta atención a la particularidad iconográfica que aquí comentamos, más atenta a otros aspectos generales compositivos. En todo caso, entre los ejemplos elegidos, sólo en uno de los medievales hay un obispo, al que se refiere sin más, como "un obispo mitrado" ("évêque mitré") (II, p. 146). Es la pieza a la que nos referimos inmediatamente.

${ }^{37}$ C. Donovan, The de Brailes Hours, Londres, 1991, pp. 47-49, figs. 20 y 18. 
conversión del sacerdote judío en obispo dependa de que exista un texto anterior o contemporáneo que lo nombre asf.

En la apócrifa historia de Joaquín y Ana es un sacerdote de la vieja ley, quien rechaza a Joaquín y le lleva a abandonar la ciudad y refugiarse con sus ganados. Lo más común es que los pintores le representen de modo distinguido, pero no como obispo. Sin embargo, en las mismas "Horas de Brailes" existe un encabezamiento lateral al lado de varias escenas, entre ellas, ésta. Se habla de que Joaquín fue al templo y "l'evesque refusa sa offrende". A consecuencia de ello, vemos a Joaquín ante un obispo mitrado ${ }^{38}$. Si volvemos a Francia, las "Grandes Horas de Jean de Berry" recogen la idea y vuelven a reproducir como antes el interior de una iglesia con altar en el que se llega a ver una menuda retrotábula. No sólo Joaquín, sino Ana se arrodillan ante él y son rechazados por un gesto del obispo mitrado (fol. 8).

No obstante, terminaré refiriéndome a una pieza problemática, una prolija caja o cofre de marfil, supuestamente francés, que custodia el museo Saint-Raymond, de Toulouse, y que se fecha a fines del siglo $\mathrm{XIV}^{39}$. Contiene una impresionante serie de escenas de la vida de la Virgen y de Jesús, sin paralelo en el arte de la eboraria francesa, como ha sido puesto de manifiesto ${ }^{40}$, hasta suponer que ello se debe a una influencia exterior. Entre las 32 historias, una corresponde a los desposorios y alli el sacerdote es un obispo. Pero ya anteriormente, cuando María niña sube los escalones del templo la recibe un obispo y otro tanto sucede cuando el sacerdote prepara las varas secas de los pretendientes y aún en otras ocasiones. ¿Debemos considerar esto una excepción francesa o estaremos ante una producción de la hasta ahora escasamente tratada eboraria hispana?

En cuanto a la Presentación en el Templo, Purificación de María o Circuncisión de Jesús hemos visto que raramente se califica de obispo

${ }^{38}$ Donovan, Op. cit., pp. 44-45, fig. 15 , de nuevo correspondiendo con las horas de la Virgen (fol. 1v.) que se inician de este modo.

${ }^{39}$ R. Koechlin, Les ivoires gothiques francaises. reimp. París, 1968, II, cat. $n^{\circ} 821$, pl. CXIIII y CXIV.

${ }^{40}$ Koechlin, Op. cit. , II, p. 301. 
a Simeón o al responsable de recibir a Jesús ${ }^{41}$. Sin embargo, mientras en el arte italiano o flamenco se tiende a presentar al anciano con la cabeza desnuda, cubierta con un velo o tocada con un gorro más o menos caprichoso, en lo hispano, lo inglés y lo francés es fácil que se cubra con una mitra, pudiendo citarse en lo primero ejemplares de casi todas las escuelas regionales, mientras hemos tenido ocasión de mencionar algún ejemplo inglés.

Recordemos ahora al Maestro de Jouvenel des Ursins, identificado con André d'Ypres, que entre 1455 y 1460 realiza dos "Libros de Horas" (Nueva York, J. P. Morgan Library, Ms. 199, fol. 95; Londres, British Library, Ms. Add. 28785, fol. 78) en los que el representante judío en la Presentación de Jesús en el Templo es un obispo mitrado ${ }^{42}$.

Entre las piezas castellanas más antiguas tenemos el gran retablo de escuela toledana del arzobispo Sancho de Rojas (M. del Prado), donde es en la Purificación cuando un obispo recoge al Niño de los brazos de María.

El asunto es tanto más interesante cuanto que en la Circuncisión del retablo de la capilla de San Eugenio de la catedral de Toledo, el oficiante lleva un gorro puntiagudo no confundible con una mitra. $Y$ digo esto porque se trata de una obra quizás italiana de un artista relacionado con el maestro que pinta el retablo de Sancho de Rojas ${ }^{43}$. El italiano, siguiendo una iconografia propia, no busca esa identificación, mientras lo hace el hispano aunque depende estilísticamente de ellos ${ }^{44}$.

${ }^{41}$ Por ejemplo, fray fñigo de Mendoza en sus famosas "Coplas de Vita Christi" le llama sencillamente el "buen biejo Simeon" (I. Rodríguez- Puértolas, Fray Ínigo de Mendoza y sus "Coplas de Vita Christi", Madrid, 1968, 159, p. 382).

42 Ver reproducidos en $\mathrm{Ch}$. Sterling, La peinture médiévale à Paris. 1300 1500,11 , Paris, 1990, figs. 120 y 121 .

${ }^{43}$ Estos ejemplos y otros en F. J. Sanchez Cantón, Nacimiento e Infancia de Cristo (Los grandes temas del arte cristiano en España. I Serie cristológica 1), Madrid, 1948, figs. 90 y ss. Curiosamente, no le preocupa el asunto de la metamorfosis del oficiante judío en obispo (pp. 73 y ss.).

44 El último estudio general sobre el retablo (M. A. B. Piquero, La pintura gótica toledana anterior a 1450 (El Trecento), Toledo, 1984, II, p. 104) llama la atención sobre el hecho de que Simeón no era sumo sacerdote, pero se le 
En el arte aragonés es relativamente corriente, siempre con la indefinición entre Purificación o Presentación en el templo y Circuncisión. Lo vemos en el antes citado retablo de la Virgen de Nicolás Zahortiga de la colegiata de Borja o en el tardío de la misma advocación realizado por Miguel Ximénez con ayuda de su hijo Juan y Martín de Larraz ${ }^{45}$. Ya en la Corona castellana, en el gran retablo del monasterio de La Sisla del museo del Prado en el que interviene el Maestro de Ávila ${ }^{46}$, la Circuncisión (fig. 9) se presenta aś, mientras en la Presentación no existe obispo. Los casos son relativamente frecuentes en este nuevo espacio geográfico, como en los retablos de Santa María del Castillo en Frómista (Palencia), el de Alcocer (Guadalajara) y el de la colección Alvear de Cádiz, que da nombre a un anónimo, ${ }^{47}$ entre otros. Podría completar las menciones con más ejemplares de Valencia (las alas del tríptico de Acqui Terme, cuya tabla central es de Bartolomé Bermejo, realizadas por Rodrigo Osona, donde está la Circuncisión) o Andalucía (el gran retablo de la Virgen de Alanís de la Sierra en la provincia de Sevilla). Una vez más he de mencionar el "Libro de Horas" de la Walter Art Gallery, de Baltimore, donde en la Presentación en el Templo de gran tamaño, correspondiente a nonas de la Virgen (fol. 68v.), así se ve ataviado al oficiante, mientras no lo está en la Circuncisión, mucho menor (fol. 41). Pero en la escuela parisina del tardo internacional debió de ser fórmula común, como se deduce de algunos manuscritos como unas "Horas" de la British Library (Londres, Add. MS. 31834, fol. 66), del segundo cuarto del s. XV, ${ }^{48}$ y la "Horas de Alejandro VII" (Vaticana, Chig. C. IV 109, fol. 64v.), próximas compositiva y cronológicamente ${ }^{49}$.

representa mitrado, aunque no saca ninguna conclusión.

${ }^{45}$ Mañas, Op. cit., pp. 174-176.

${ }^{46}$ Esto lo mantuve hace ya tiempo, J. Yarza, La Edad Media (Historia del Arte Hispánico II), Madrid, 1980, p. 420, afirmando lo mismo M. Díaz Padrón, muy posteriormente, pero sin citar mi hipótesis.

${ }^{47}$ Silva, Op. cit., Il, pp. 637 y ss., fig. 204.

${ }^{48}$ J. Backhouse, Books of Hours, Londres, 1985, p. 32, fig. 30.

${ }^{49}$ Biblioteca Apostolica Vaticana. Liturgie und Andacht im Mittelalter, Colonia, 1992, $\mathrm{n}^{\circ}$ 52, pp. 250-251. 
Sin embargo, tal vez la escena que causa más extrañeza entre aquéllas que aplican este sistema de signos significativos es la Crucifixión multitudinaria, que se desarrolla desde fines del siglo XIII, con un grupo arracimado de personas entre las que está un obispo. No se trata de varios, sino tan sólo de uno. Los evangelios, como ya comentamos, se prestaban a estas presencias al aludir a los príncipes de los sacerdotes que increpaban a Cristo. Sin embargo, me consta que en pocos lugares se hizo uso de esta forma de entender el texto bíblico, como no fuera en casos muy especiales y, por lo general, más tardíos. La principal excepción es Cataluña. De hecho, ni aun se puede decir de un modo amplio que debamos referirnos a todo este ámbito territorial, sino que es la escuela de Barcelona y a partir de Lluis Borrassa, no antes, la que introduce esa extraña variante iconográfica.

La mayoría de los retablos góticos presentan en su ático una Crucifixion. Muchas veces ésta se reduce al Crucificado entre la Virgen y Juan, pero en el siglo XIV son conocidos en toda Europa, especialmente en Italia, estos complejos escenarios con numerosas figuras positivas y negativas, instaladas a ambos lados de altísimas cruces. Pero en la muchedumbre que se mueve a caballo al lado derecho, izquierdo del Crucificado, no se encuentra nadie vestido como obispo. Recuérdese la magnifica y escenografica composición de Pietro Lorenzetti en la iglesia baja de San Francisco de Asís, entre las primeras dotadas de tal monumentalidad, donde no hay elementos distintivos suficientemente claros para distinguir los soldados romanos y otros que están con ellos, del grupo de los judíos. Lo que puede ocurrir en otras similares circunstancias es que figuren dos señales o estandartes, incluso repetidos. En uno se ven las capitales S.P.Q.R. alusivas a los romanos, mientras en el otro se encuentra un escorpión que los identifica con los judíos $^{50}$. Como se trata de señales, los portadores suelen ser en ambos casos guerreros, aunque no se entiende bien, desde una perspectiva racional, quiénes deben ser considerados tales entre los judios. En el arte francés que recoge esta tradición iconográfica monumental italiana, se repiten igualmente ambos signos.

${ }^{50}$ Sobre esto último, M. Bulard, Le Scorpion, symbole du peuple juif dans l'art religieux des XIVe, XVe, XVIe siècles, Paris, 1935. 
Los retablos catalanes de influencia italiana rematan con Crucifixiones cuyas menores dimensiones reales requieren una reducción de las multitudes que llenan sus modelos. Pero no hay ningún elemento llamativo iconográficamente entre las obras de los Bassa, Destorrents y Serra. El cambio sobreviene al menos desde el retablo ya mencionado de la Virgen y San Jorge de San Francisco de Vilafranca del Penedés, que se atribuye a una primera etapa de la obra de Lluis Borrassa, y donde ya un seudo obispo preside los desposorios de María y José. En el ático con la consabida Crucifixión, a la izquierda, entre varios soldados, cabalga un obispo, sin duda uno de los príncipes de los sacerdotes del texto brblico. Se remarca la contraposición con el grupo de la izquierda formado por María, Juan y las santas mujeres. Tampoco quiere decir que a partir de este momento el personaje haga continuo acto de presencia. Falta en bastantes retablos, incluso del mismo artista.

Vuelve a encontrarse en otros, como el de San Pere de Terrassa (Terrassa, ig. de Santa Marfa), muy posterior (h. 1411-1413), donde el despliegue de señales es más llamativo. Está, no obstante en el lado "positivo", a nuestra izquierda, señalando al Crucificado, como corresponde a quien se dirigió a él de forma ofensiva. Es siempre un anciano barbado a caballo, que apunta con su dedo a Jesús, como en el magnífico y amplio conjunto de Santa Clara de Vic (M. Diocesano, Vic). Añadiremos a éstos, con el obispo de nuevo a la izquierda, el retablo de San Miquel de Cruilles (M. Diocesano, Girona), la Crucifixión suelta que estuvo en la col. Hartmann de Barcelona (con un obispo imberbe) y los restos del retablo de su escuela proveniente de San Llorenç de Morunys (M. Diocesano, Solsona), muy lastimados y apenas recuperados en una restauración reciente.

$\mathrm{Ni}$ aun otros contemporáneos del artista, como Jaume Cabrera, adoptaron esta moda iconográfica. No sabemos cuál fue el motivo de que lo hiciera él, aunque quizás existiera una razón. En algunos de los contratos de obras hay algunas indicaciones precisas para que en la Crucifixión no se olvide de los judfos, como en el de Sant Pere de Salavinera de 1392, perdido. Se dice: "Dalt, le istoria del Crucifix, ab les Marfes, e sanct Johan, e jueus, saguons que's pertany de la 
istoria" ${ }^{51}$. Las cláusulas del contrato de otro retablo dedicado a los apóstoles Santiago el Menor y Bartolomé, para San Francisco de Vilafranca del Penedés, repiten casi palabra por palabra las indicaciones que afectan a la Crucifixión ${ }^{52}$. Una y otra vez se recalca que ha de estar el Crucificado, María o las tres Marías, Juan y los judíos. En una ocasión se concreta más: "jueus armats", como si con ello se pusiera de manifiesto que todo el grupo que completa la composición estuviera constituido por judios ${ }^{53}$. En ningún caso se menciona a los soldados romanos, aunque luego figure el distintivo mencionado en las pinturas. Hay pequeñas variantes, como en el retablo de San Pedro de Santa María de Manlleu en 1403, en el que se le indica que los judíos han de estar a caballo, además de Longinos con la lanza ${ }^{54}$.

La razón de que estén presentes siempre los judíos es debido a que se les responsabiliza de la muerte de Cristo más que a los romanos, como en el retablo de la Virgen de las clarisas de Vilafranca del Penedès: "Le istoria del Crucifix, so és, com fo crucifficat per los juheus". Éstos deben ir armados y a caballo ${ }^{55}$. Tal vez existio, bien un texto, bien un primer mentor que al encargar una obra a Borrassà le dijo que, entre los supuestos judíos deicidas armados y a caballo, uno había de ser príncipe de los sacerdotes y por ello vestiría ropas sacerdotales y se tocaría con mitra de obispo. Creada la fórmula la repetición sería fácil, basándose el pintor en la frase siempre reiterada de que todo se había de hacer según se acostumbraba. El interés que esta presencia tiene ha de medirse por la importancia real que la Crucifixión como motivo de meditación alcanza entonces en toda Europa en general y en Cataluña en particular. Sin embargo, también el motivo podría haberse importado de Francia en un momento y unas circunstancias precisas, como sugeriremos más adelante.

${ }^{51}$ J. M. Madurell, "El pintor Lluis Borrassà. II Apéndice documental", en Anales y Boletín de los Museos de Arte de Barcelona, VIII (1950), $\mathrm{n}^{\circ}$ 91, p. 87.

${ }^{52}$ Madurell, Op. cit., n* 92, p. 89.

${ }^{53}$ Madurell Op. cit., $\mathrm{n}^{\circ} 134, \mathrm{p} .139$.

${ }^{54}$ Madurell, Op. cit., $\mathrm{n}^{\circ}$ 140, p. 151.

${ }^{55}$ Madurell, Op. cit., $\mathrm{n}^{\circ}$ 143, p. 156. 
Si es cierto lo que supongo, la fórmula arraigó en Barcelona, de modo que la vemos repetida sin variantes esenciales en Joan Mates. En el sucio retablo de los santos Martín y Ambrosio de la catedral de Barcelona, fundamental para conocer el estilo del maestro, documentado ampliamente (1411-1414), pero sin que se precisen las condiciones iconográficas como en las obras de Borrassà. La solución compositiva elegida no difiere mucho de la de éste, estando el obispo a caballo a la derecha, señalando hacia Jesús. Extremadamente similar es la solución elegida en el retablo de Vila-rodona tambien documentado más tarde (h. 1422-1423). Como Borrassà, hay otras pinturas en las que no se encuentra el obispo.

El heredero principal del gran taller del pintor gironí en Barcelona fue Bernat Martorell, quien conoció tiempos más difíciles, si bien no impidieron que se le encargaran multitud de pinturas. Desde las primeras adoptó la fórmula comentada. En la exquisita pieza dedicada a San Juan Bautista procedente de Cabrera de Mataró (M. Diocesano, Barcelona) (fig. 10) el único cambio apreciable consiste en presentar al obispo y los soldados a pie, tal vez por la pequeñez de la tabla, porque en el tardío de la Transfiguración, de la catedral de Barcelona y de grandes dimensiones, vuelven a verse grupos numerosos y a la derecha a caballo, visto casi de espaldas, está otra vez el obispo ${ }^{56}$.

La secuencia barcelonesa termina con Jaume Huguet, que de idéntica manera se hace heredero de la fórmula iconográfica. En algunas ocasiones se limita a aceptarla sin modificación, como en el destruido retablo de san Antonio Abad, donde se veía al obispo a caballo a la izquierda, conversando con el centurión. Igual sucede en el retablo de San Martín de Partegás de Sant Celoni (M. Nacional de Arte de Catalunya). Seguramente, más singular es la Crucifixión que culmina el retablo de los santos Abdón y Senén en Santa María de Terrassa (fig. 11). Como la tabla es muy ancha y baja, todos están de pie y en grupos desdramatizados, como conviene al genio del artista. Completamente a la derecha, el anciano obispo habla con un soldado al que señala algo en la misma dirección. Se ha desentendido de lo que sucede en el

${ }^{56}$ Sin pretensiones de ser exhaustivo, recuerdo que también se encuentra en el desmembrado retablo de los santos Juanes de Vinaixa y en el fragmentado de Banyeres del Penedès (Barcelona, col. privada). 
centro. No increpa al Crucificado ${ }^{57}$. El patetismo que la historia requiere no existe y en su lugar vemos a grupos en conversación, alcanzando tal actitud hasta a Juan y las Santas Mujeres ${ }^{58}$.

Repetido en múltiples obras de la escuela pictórica de Barcelona, se diría que es en ella donde hay que buscar el origen de la fórmula iconográfica. Seguramente es así, pero lo cierto es que de manera más ocasional no deja de verse en otras escuelas. Citemos cuatro ejemplos. El primero es francés y se trata de nuevo de las "Horas de Etienne Chevalier" (M. Condé, Chantilly) de Jean Fouquet. En la amplia escena espléndidamente resuelta hay un grupo de principales a caballo y de espaldas que mira a Jesús. El del medio es un robusto personaje, cuyas ropas diff́cilmente calificarfamos de episcopales, pero sin embargo va tocado con una mitra. El segundo ejemplo procede de Aragón y concretamente del retablo mayor de la parroquial de Blesa (M. de Zaragoza), pintado por Martín Bernat y Miguel Ximénez. Entre la densa masa de personajes que pueblan la Crucifixión se distingue un grupo a la izquierda, casi con seguridad judíos y, entre ellos, un individuo tocado con mitra, aunque viste con ciertas particularidades, como si se quisiera distinguir del obispo cristiano. El retablo se data entre 1485 y 1487, por tanto, es el ejemplar más moderno de los mencionados. ¿Cómo se deben entender ambos casos? ¿Tal vez como reliquias de una costumbre más generalizada, como signo de una influencia del arte catalán, o más concretamente barcelonés, o como verdaderas excepciones? En el caso francés cabría creer que pudo haber otras pinturas perdidas, dada la destrucción del patrimonio pictórico de este país correspondiente al siglo $\mathrm{XV}$, pero yo diría que estamos ante una excepción, comprobada en otros ejemplos mencionados y por mencionar del gran pintor. Sin embargo a esto se podrían oponer los otros dos casos, ambos anteriores.

${ }^{57}$ J. Yarza Luaces, Jaume Huguet i el retaule dels sants Abdò y Senèn, en: Terme, $\mathrm{n}^{\circ} 9$ (1994), pp. 25-38.

${ }^{58}$ Aunque deben existir otros ejemplos se diría que en lo sustancial hasta aquí ha llegado la curiosa fórmula. Entre otras obras que se hacen eco aún, el retablo mayor de la iglesia de San Esteban en La Doma (Vallés Oriental) (Gudiol-Alcolea, Op. cit., $\mathrm{n}^{\circ} 639, \mathrm{p} .198$, fig. 988). 
¿Es posible creer que veamos un obispo en un personaje singular de la crucifixión de las "Horas de Jeanne de Evreux", de Jean Pucelle, de hacia 1325-1328 (M. Cloisters, fol. 68v.) (fig. 12) ? Se sitúa a la izquierda en alto y está tocado con un gorro que podría sugerir que es una mitra. Añadamos una nueva miniatura, claramente más tardía. En el "Salterio Fitzwarin" (Parfs, Bib. Nat., Lat. 765, fol. 14), inglés y poco posterior a mediados del siglo XIV, se repite la imagen ${ }^{59}$. De ser así en el primer caso, podríamos estar en el origen real de la fórmula iconográfica que tanta vida llegó a tener en Cataluña. Existe, por otro lado, una coincidencia entre su aparición aquí y la llegada de obras francesas parisinas, alguna de las cuales se refleja en el "Breviario de Martín el Humano" (París, Bib. Nat., Ms. Rotschild 2529), como la organización del Calendario que depende lejanamente del "Breviario Belleville" de Pucelle. Por el contrario, en la obra aragonesa sería permisible suponer un cierto influjo catalán, aunque no se acuse en otros artistas y precisamente los autores de este retablo estén sobre todo influidos por Bartolomé Bermejo, si bien nos encontramos ante un detalle iconográfico y no estilístico. Lo que es cierto es que ambos son muy posteriores a las primeras obras catalanas.

Sabio y piadoso alfaquí musulmán, gran sacerdote pagano de diversas religiones, dios astrológico de la antigüedad, príncipe de los sacerdotes de la ley mosaica, en la Edad Media, y de manera bastante singular en los reinos hispanos, se decidio que coincidían en un punto: eran religiosos de alta jerarquía, por ello comparables a los obispos. De aquí a representarlos como tales o a citarlos igualmente en los textos no había sino un paso. Desde luego, los dioses planetarios constituyen una excepción. En los "obispos" judíos se dan otros diversos motivos que justifican esta presencia, como en alguna circunstancia puede ser el que se confundieran las cosas y se diera por válido el que sus antiguas vestiduras $y$ tocados coincidían con los propios cristianos $^{60}$. En

${ }^{59}$ Mellinkoff, Op. cit., p. 152.

${ }^{60}$ Es en lo esencial la tesis de Mellinkoff, $O p$. cit., que asimismo busca el origen del tipo de mitra en una semejanza con la aparición de los cuernos de Moisés, objeto de un estudio anterior. A mi juicio, en líneas generales, es más probable la aplicación de este principio de disyunción medieval, que produce un lenguaje fácilmente inteligible, que las razones aducidas por Mellinkoff. 
Francia, bastante normal, en Inglaterra, también, infrecuente por no decir inexistente en Italia y casi lo mismo en los Países Bajos, aqui fue en extremo corriente, aunque no obligado, provocando situaciones tan disparatadas como la de Borrassà en Santa Clara de Vic.

Hubo textos que debieron servir de guía para las imágenes, pero no siempre coinciden ambos en importancia. Anás y Caifás son calificados de obispos en inglés, castellano y catalán, pero es difícil encontrarlos como tales en la pintura hispana. Casi nunca se ve un obispo en los escenarios que ha de visitar Jesús después de su prendimiento y hasta que llega a cargar con el peso de la cruz. Veamos al menos un ejemplo en lo europeo, más concretamente en Francia. En el "Libro de Horas" del Maestro de la Leyenda Dorada de Munich, en una escena inequfvoca (fol. 108), aunque secundaria, un notable obispo, Caifás o Anás, recibe a Jesús.

Cabe, eso sí, hablar de falsos obispos entre los judíos que siguen los momentos de la pasión, previos a la Cruz. Aś, el tantas veces citado Jean Fouquet vuelve a incluir uno entre los principes de los judíos que reclaman la muerte de Jesús a Pilatos en sus "Horas de Etienne Chevalier", aunque no sea especificamente Anás o Caifás. Precisamente es aquél que señala a Jesús y forma parte de un grupo de principales judíos, siempre vestido de modo que no acaba de identificarse con un obispo cristiano, pero portando mitra sobre la cabeza ${ }^{61}$. Una

${ }^{61}$ Las Horas de Fouquet no sólo es una de las obras maestras del arte del siglo XV, sino una de las notables desde la perspectiva iconográfica. Se conserva como "membra disiecta" sólo fragmentariamente y en folios sueltos la mayoría de los cuales está en Chantilly (Ver todas las imágenes en G. Bazin, Jean Fouquet. Le Livre d'Heures d'Etienne Chevalier, París, 1990). Incluso se ve que por coherencia había de representar aun una vez más un falso obispo. Así primero se encuentra en la escena de Pilatos. Luego, en el Camino del Calvario hay una amplia comitiva y delante se distingue a caballo un personaje de espaldas que ha de ser el mismo, siendo perceptible la mitra que lleva. La última imagen se encuentra en la Crucifixión. No obstante y pese al interés que el tema tiene en Fouquet se diría que ni siquiera entonces resuelven el problema de la misma manera los artistas hispanos. Fouquet introduce elementos de diferencia en las ropas, mientras los pintores hispanos representan más fielmente a los obispos en todo. De todos modos Fouquet tuvo modelos en Francia. En el folio desgajado de las famosas Grandes Horas de Jean de Berry varias veces mencionadas, con el camino del Calvario, obra maestra probable de Jaquemard de Hesdin, es clara 
vez más parece que hay antecedentes hispanos, concretamente catalanes. El "Libro de Horas de María de Navarra", de Ferrer Bassa y su taller (Venecia, Biblioteca Marciana, Lat. I. 104), presenta un obispo cerca de Pilatos en las Horas de la pasión (fol. 227). Todavía resulta más singular la Flagelación (fol. 219v.) (fig. 13) del mismo oficio, porque en ella flanquean a los verdugos dos claros obispos mitrados, sin duda judíos (príncipes de sacerdotes) ${ }^{62}$. Esta insistencia quizás suponga un antisemitismo marcado, porque les hace figurar, sin lugar a dudas, en una nueva escena cruenta, como si se les convirtiera más que en observadores pasivos, en agentes de la agresión a Cristo.

El asunto no queda agotado. No ya porque no se pretendía recoger todas las imágenes, sino porque aun en otras circunstancias hay individuos mitrados de difícil explicación. ¿Qué decir del obispo al que parece dirigirse San Miguel en el retablo de Castelló de Ampurias (M. Diocesano y Provincial de Girona), recientemente documentado como obra de Joan Antigó y Honorat Borrassà? (fig. 14). Junto a él está el cuerpo muerto de Moisés, lo que nos sitúa en el Antiguo Testamento.

Hemos de tener presente que nos encontramos en un terreno todavía no comentado en el que se dan cita, desde Moisés y Aarón a los posteriores sumos sacerdotes judíos. De hecho, hasta un personaje como Melquisedec podría haber sido calificado de obispo por una mente medieval, si no fuera porque de él se dice que era rey y sacerdote y suele representarse con corona. Pero sólo a manera de ejemplo, quizás excepcional, tomemos un caso en el que hubo algún intento de poner de relieve su doble condición, como en el francés "Salterio de San Luis" (París, Biblioteca Nacional, Lat. 10525, fol.6), haciéndose el miniaturista eco del texto: "Melchicedech le roi et esveque". Pero es claro que a otros personajes posteriores cabra llamarlos obispos.

la presencia activa de un obispo que se vuelve hacia Jesís (Thomas, Op. cit., pl. 110). ¿Invención del miniaturista o idea también prestada de Jean Pucelle? Habría que ver el papel que en la creación y difusión del seudo obispo judio tuvo Pucelle.

${ }^{62}$ R. Alcoy, Canvis i oscil-lacions en la imatge pictòrica dels jueus a la Catalunya del segle XIV. en "Actes. Ier. Col-loqui d'Història dels jueus a la Corona d'Aragó", Lleida, 1991, p. 375. Recoge otros ejemplos en el "Salterio de Paris" (Bib. Nat., Lat. 8846). 
Así sucede con uno de los escritores más importantes de la etapa gótica en catalán, Fráncesc Eiximenis. En su "Llibre dels angels" dedica su quinta parte a san Miguel, de quien dice que una de sus misiones fue dirigir a los judíos a lo largo de dos mil años. Los propios judíos talmudistas crefan que sería el protector y abogado del pueblo hebreo hasta el fin de los tiempos, enfrentado a Samael ${ }^{63}$. Pues bien, al comentar la realidad de esa guarda, que el franciscano supone que llega hasta la época de Jesús, y para decir que vigila a las autoridades de Israel va citando: "jutjes, reys e bisbes", indicando en estos últimos a los sumos sacerdotes ${ }^{64}$. En cuanto a la relación entre Miguel y Moisés, como se encuentra en el retablo de Castelló, debió existir una tradición que no alcanzo a descubrir, pero que se manifiesta en la Epistola Católica de Judas Tadeo: "Cuando el arcángel Miguel disputando con el diablo altercaba sobre el cuerpo de Moisés" (vers. 9) ${ }^{65}$. Esto da a entender que a la hora de su muerte Moisés tuvo como guardián de su lugar de enterramiento a Miguel. De hecho se nos dice que se quiso evitar la idolatría de los judíos escondiendo el cuerpo de su guía, impidiendo que lo convirtieran en objeto de culto. El guarda había de ser el protector de Israel. Pero éste lo era contra el enemigo Samael, especie de diablo. Otra tradición indicaba que Moisés habŕa sido arrebatado al cielo. De nuevo Eiximenis se hace eco de la primera tradición y la explica así: Miguel oculta el cuerpo de la vista de los judíos, porque el diablo está dispuesto a hacerles caer en la tentación idolátrica de que le adoren ${ }^{66}$.

En la pintura tenemos una variante del hecho. Miguel oculta a Moisés de la mirada de un grupo de judíos encabezados por el sumo sacerdote, quizás Aarón, que va vestido como obispo. Hay que decir que de todos modos no es frecuente esta escena. Lo cual no quiere decir

${ }^{63}$ C. Gonzalo Rubio, La angelología en la literatura rabínica y sefardí. Barcelona, 1977, p. 42.

${ }^{64}$ Francesc Eiximenis, De Sant Miquel arcàngel, El quint tractat del "Llibre dels angels", ed. C. J. Wittlin, Barcelona, 1983, IX, p. 60.

65 "Cum Michael archangelus cum diabolus disputans altercaretur de Moysi corpore".

${ }^{66}$ Eiximenis, Op. cit., cap. X, pp. 60-61. 
que no sea posible y ya no en la etapa gótica, sino precisamente en la románica. En un "Comentario al Levítico" (París, Bib. Nat., Lat. 11564, fol. 2), están Moisés y Aarón, siendo el segundo un obispo que sacrifica un ternero. La "Biblia de Burgos" (Burgos, Biblioteca Provincial), del siglo XII, posee varias iniciales del Antiguo Testamento con una figura que, según todos los indicios, es Moisés. Pues bien, en más de una ocasión lleva mitra obispal, que entonces comenzaba a tener una forma similar a la posterior que hoy conocemos ${ }^{67}$.

Hemos dejado muy atrás al alfaquí de Gonzalo de Berceo. En definitiva, estamos ante un tema amplio con múltiples variantes, bastante extendido, si bien en modo alguno ha de considerarse una fórmula iconográfica normalizada. Los casos son numerosos, pero sobre todo abundan en los reinos peninsulares, tanto en la etapa gótica, la más importante en este sentido, como en la románica, resultando hasta bastante originales algunos, como la Crucifixión en el ámbito catalán, singularmente barcelonés. En algunas circunstancias resulta llamativo y extraño, pero en la mayoría de las ocasiones ha pasado casi desapercibido hasta para los estudiosos ${ }^{68}$. La relación texto-imagen existe,

${ }^{67}$ J. Yarza Luaces, "Las miniaturas de la Biblia de Burgos", en Archivo Español de Arte, XLII (1969), pp. 185-203. Está al comienzo de Deuteronomio (fol. 79), p. 187, y antes en Números (fol. 62v.). Una búsqueda detenida nos proporcionaría quizás algún otro ejemplo. Así, en la "Hoja Morgan" (Nueva York, J. P. Morgan Library, Ms. 619), de Winchester, se presenta otro probable. Pero tampoco debe creerse que sea común. Esta fórmula llega a contaminar la iluminación de manuscritos judíos en ocasiones muy concretas. En un Mahzor de hacia 1320, supuestamente alemán (Londres, British Library, Add. MS. 22413, fol.3) el oficio de Shavuot se ilustra con una escena en la que, tras Moisés que porta las tablas, se encuentra Aarón tocado con mitra (G. Sedrajna, Le Mahzor enluminé, Leiden, 1983, p. 25, fig. 38).

${ }^{68}$ Generalmente, los que tratan la imagen del judío, están más pendientes de encontrar actitudes antisemitas, que de buscar la verdadera y diversa faz con que esta minoría se representa. Véase como ejemplo, no ya el antes citado libro de Blumenkranz, sino también estudios más recientes, como el interesante de D. Sansy, Jalons pour une iconographie médiévale du juif, en Xudeus e conversos na Historia (Ribadavia 1981), Santiago de Compostela, 1994, I, pp. 135-169, que no menciona esta particularidad tan extendida. En cuanto a la extensión del asunto, no quiero dejar sin apuntar aquí una nueva rareza. Ya en el "Salterio Oscott" (Londres, British Library, MS. Add. 50000, fol. 7) se ve a José en la Visitación, tocado con mitra (Mellinkoff, Op. cit., fig. 10). De igual modo se 
aunque no sea determinante. Si se trata de un musulmán o un pagano es más necesaria esta dependencia de la segunda respecto a la primera. En mucha menor medida si es un judío. Muchos pudieron ser los motivos para que en este o aquel momento se eligiera esta iconografía, y alguno lo hemos mencionado. Sin embargo, a mi juicio, en general prima sobre otras la idea propia de la época de "medievalizar" el mundo, de acuerdo con ese principio de disyunción de Panofsky, a fin de hacerlo más inmediatamente inteligible.

encuentra en el Nacimiento sobre esmaltes de la Cruz atribuida a Pere Berneç, en el Museo de la catedral de Girona, sobre la que me ha llamado la atención F. Español. Dejo en suspenso el interrogante sobre los motivos de tal situación. 


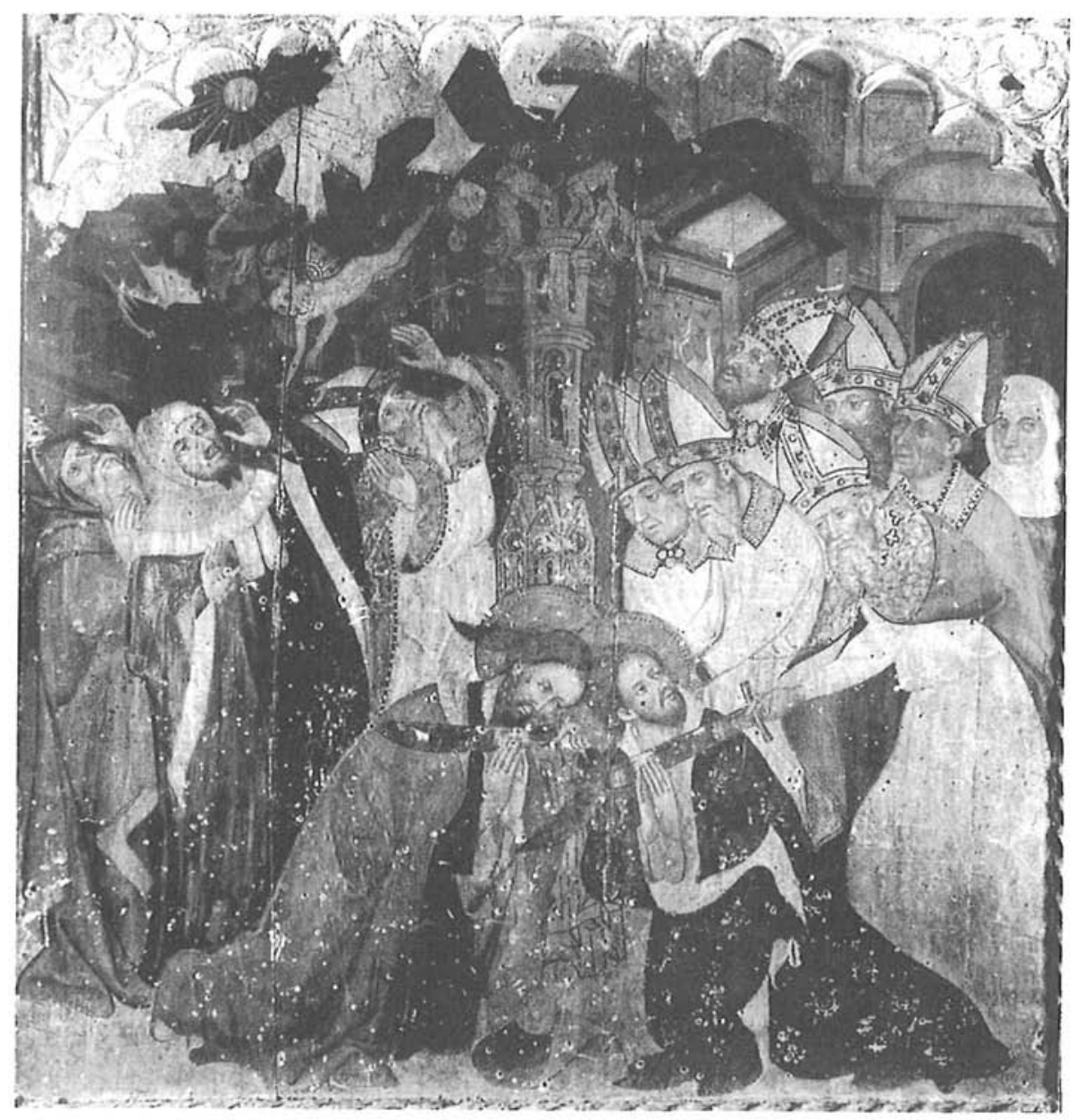

Fig. 1 


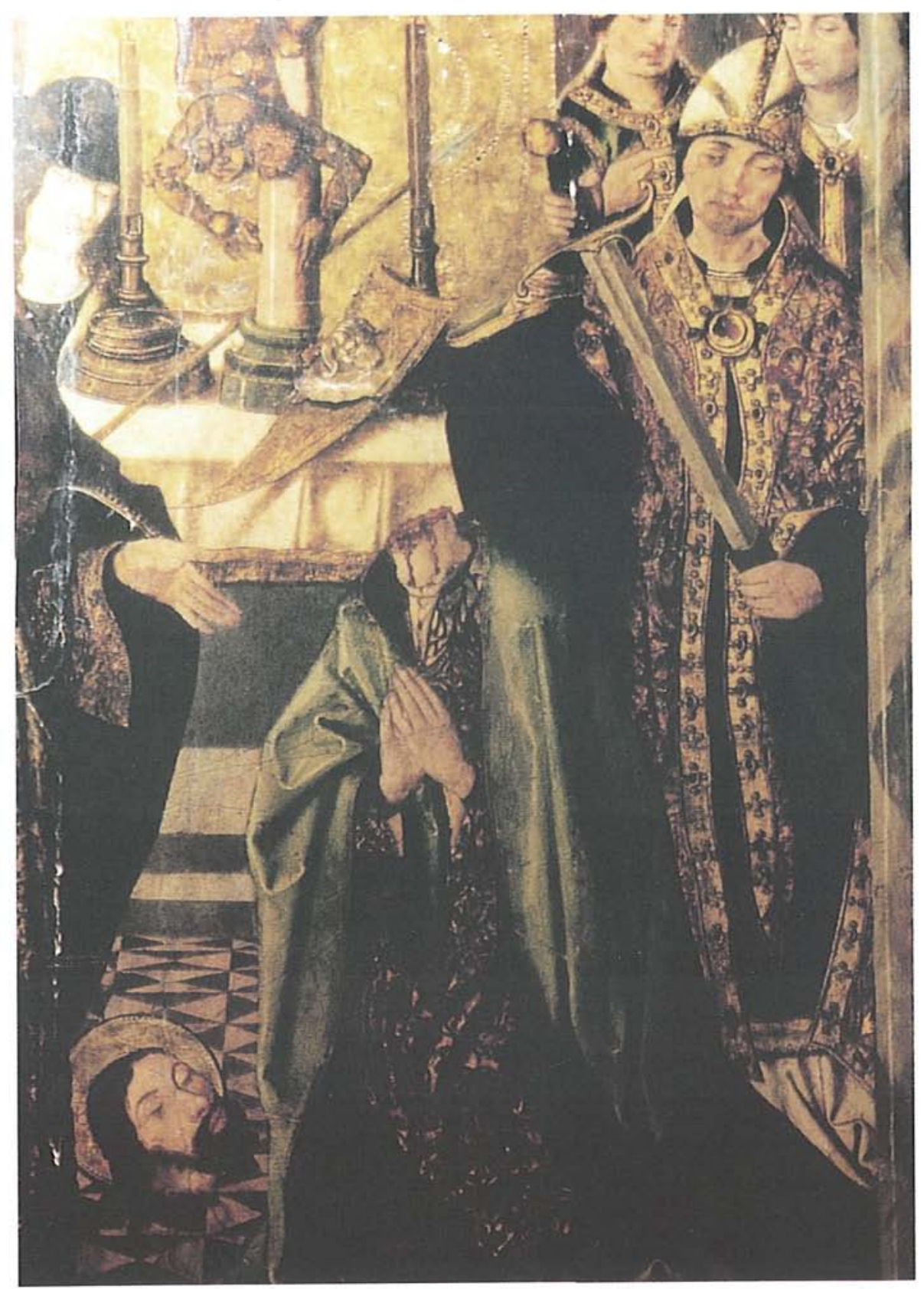

Fig. 2 


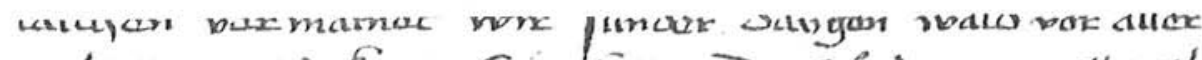

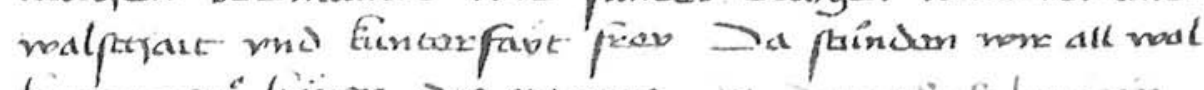

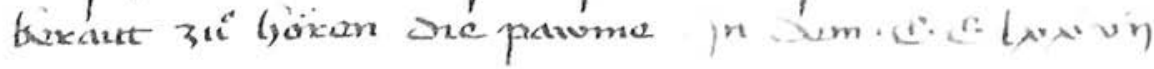

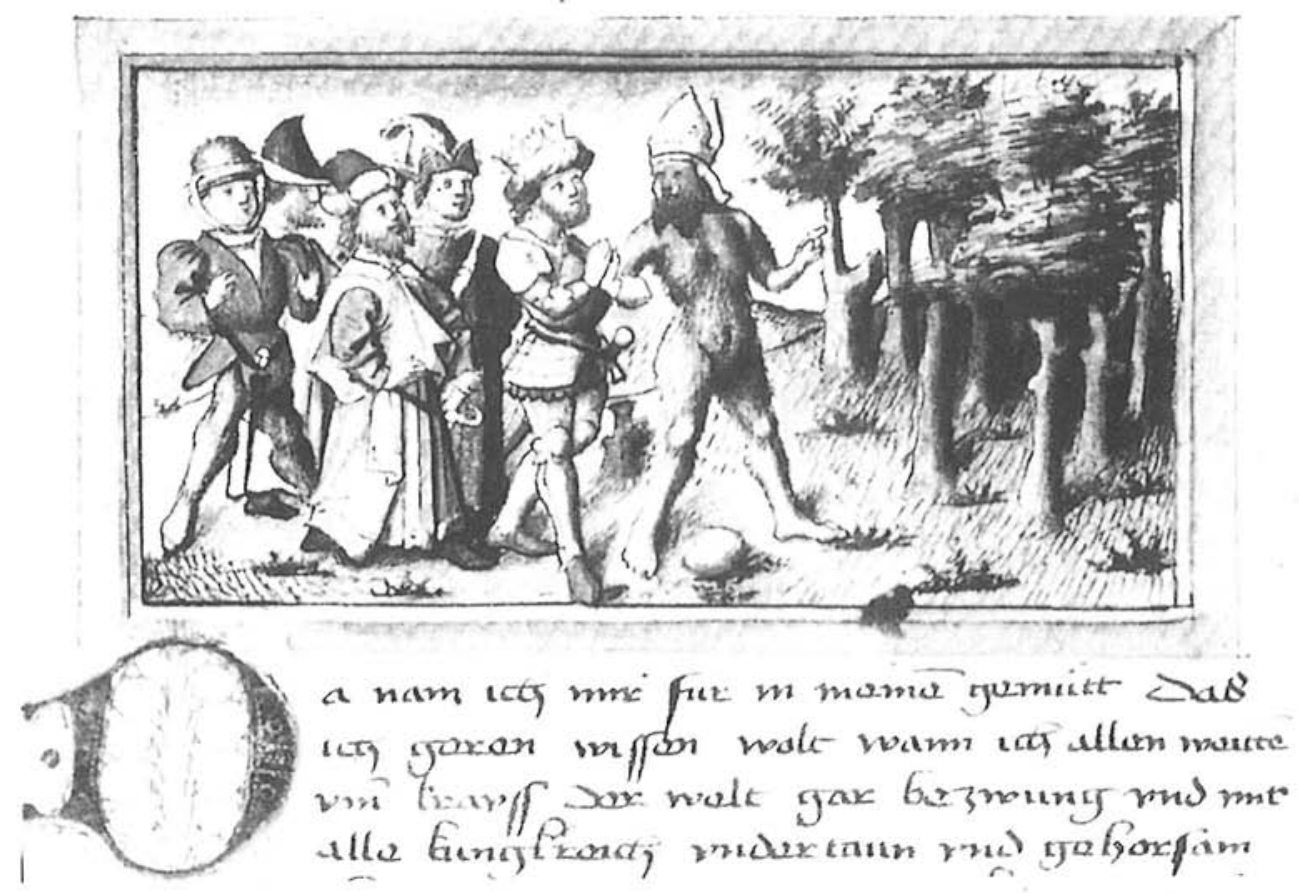

Fig. 3 


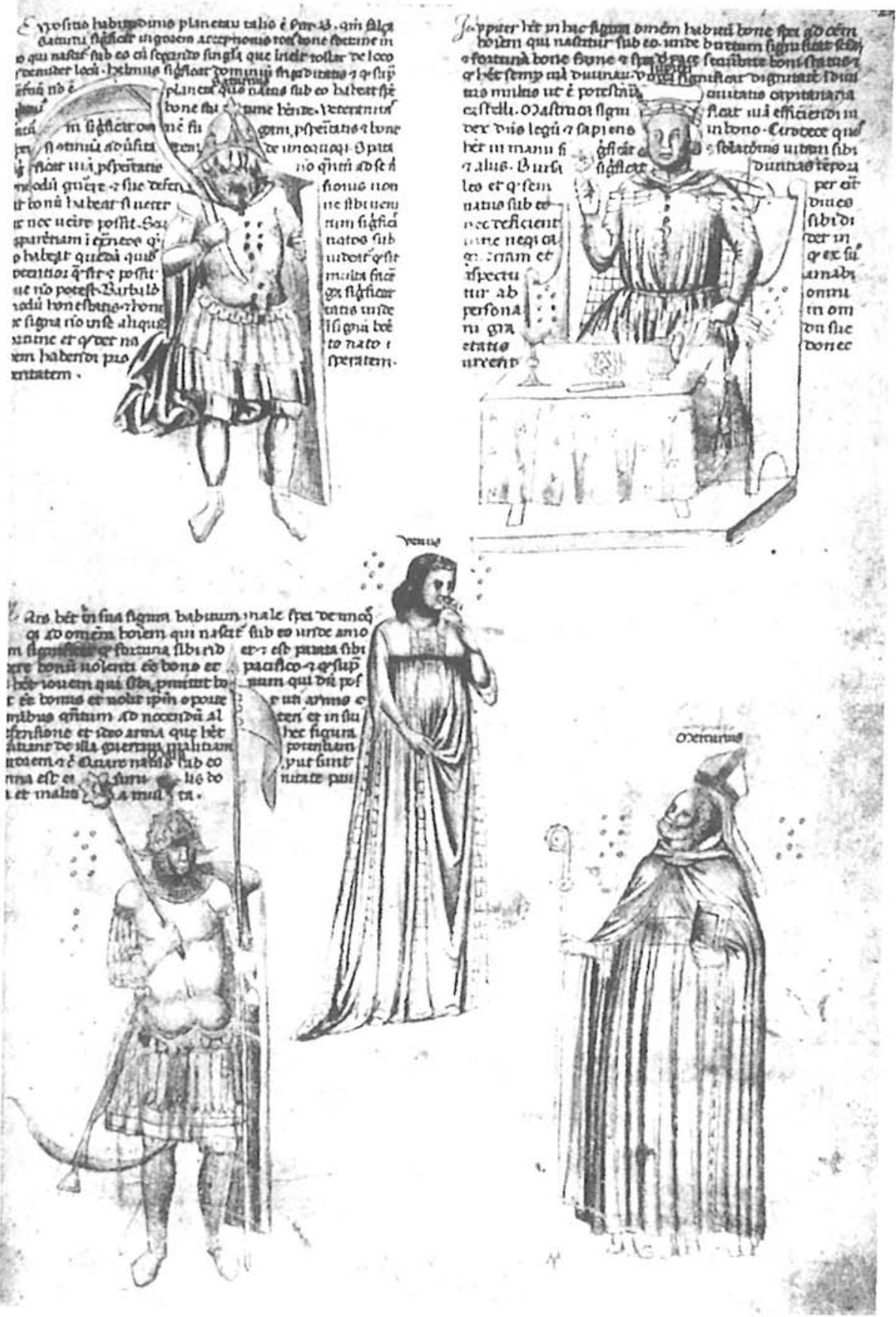

Fig. 4 


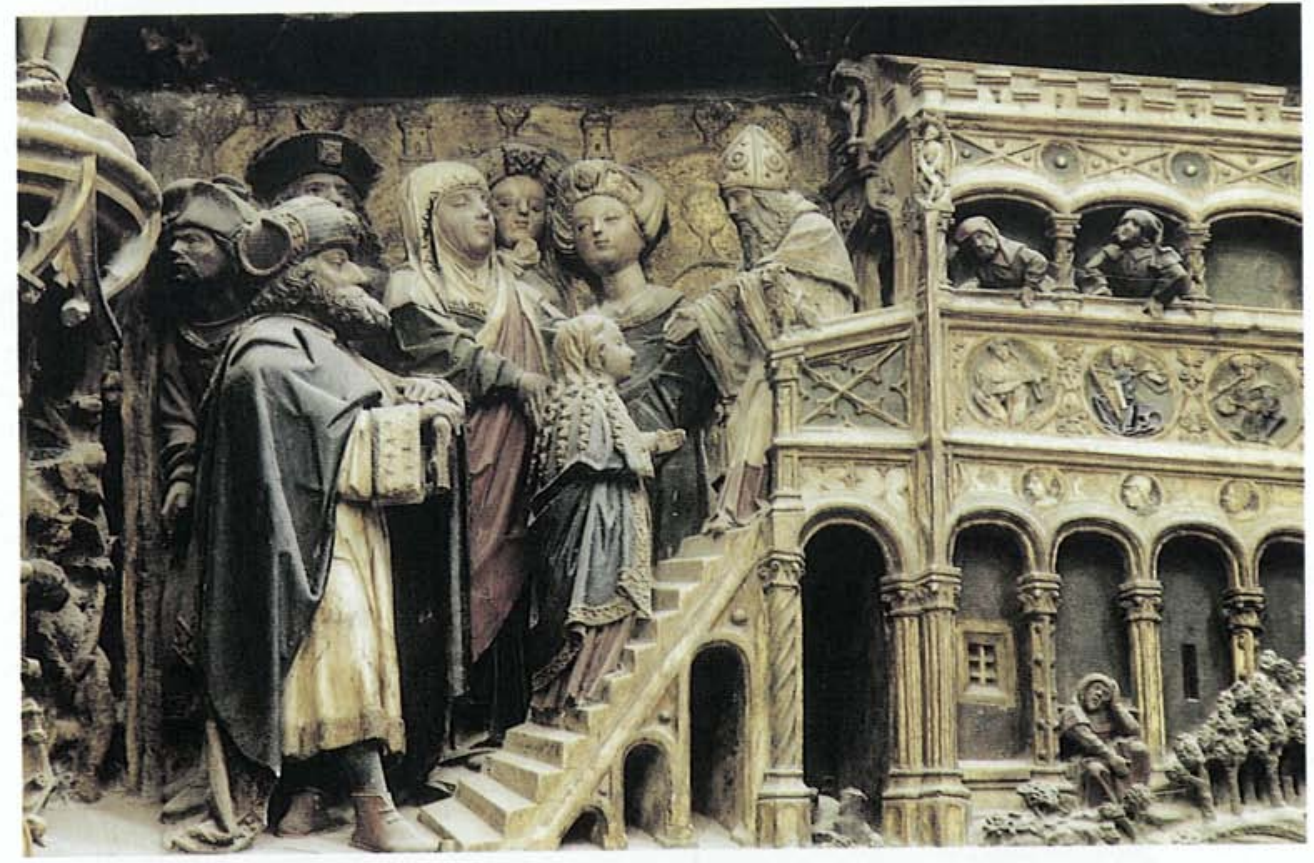

Fig. 5 


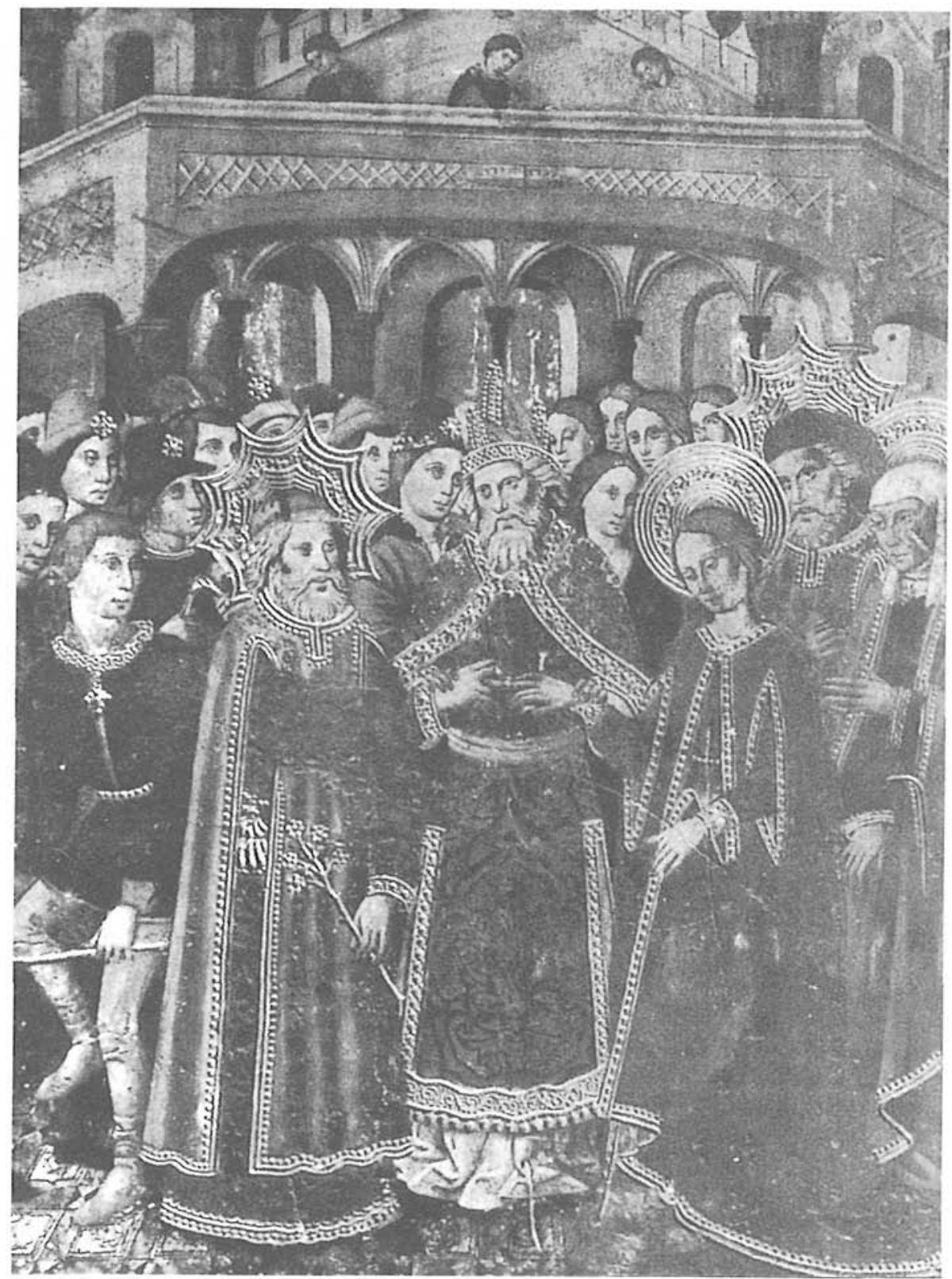

Fig. 6 


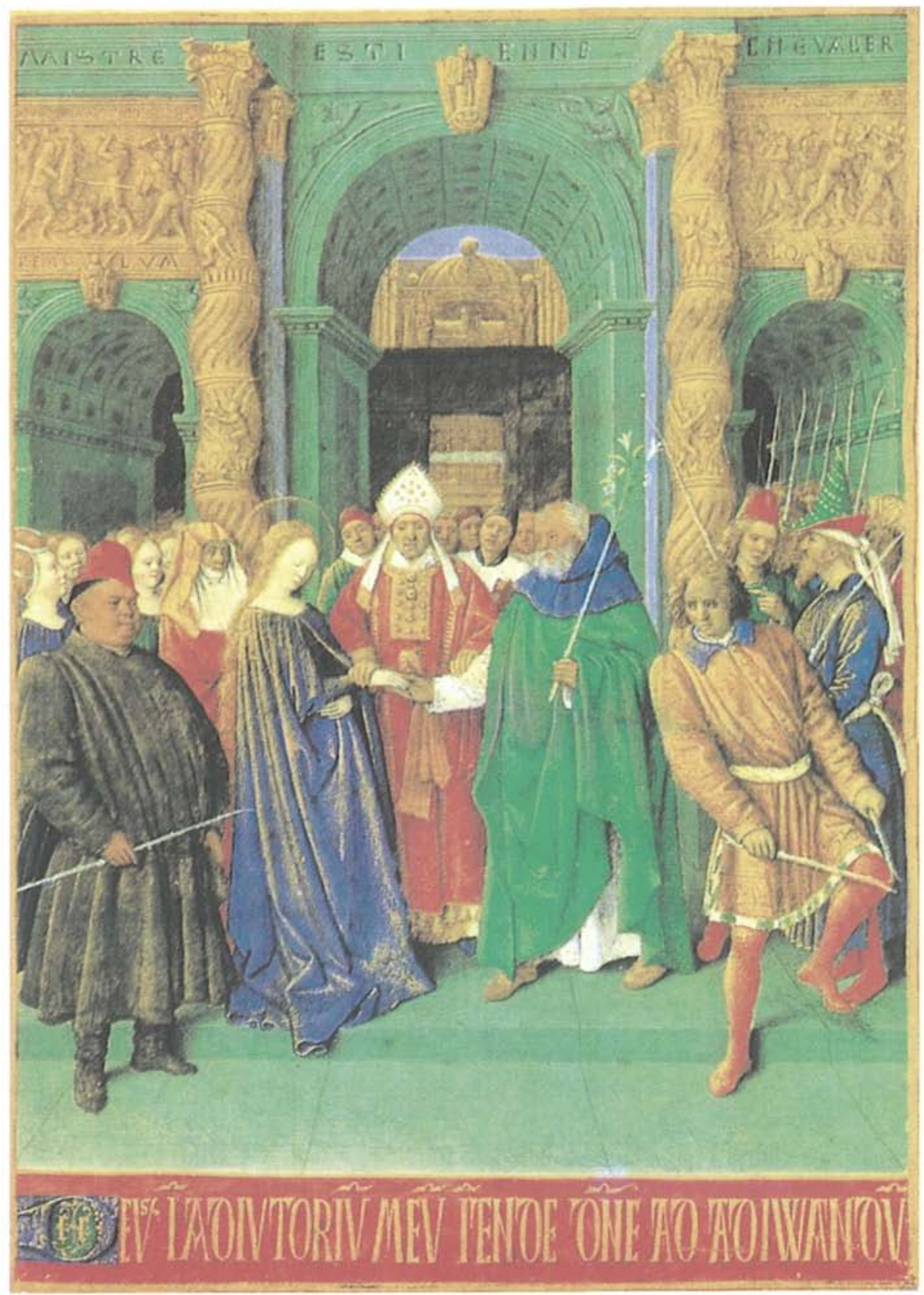

Fig. 7 


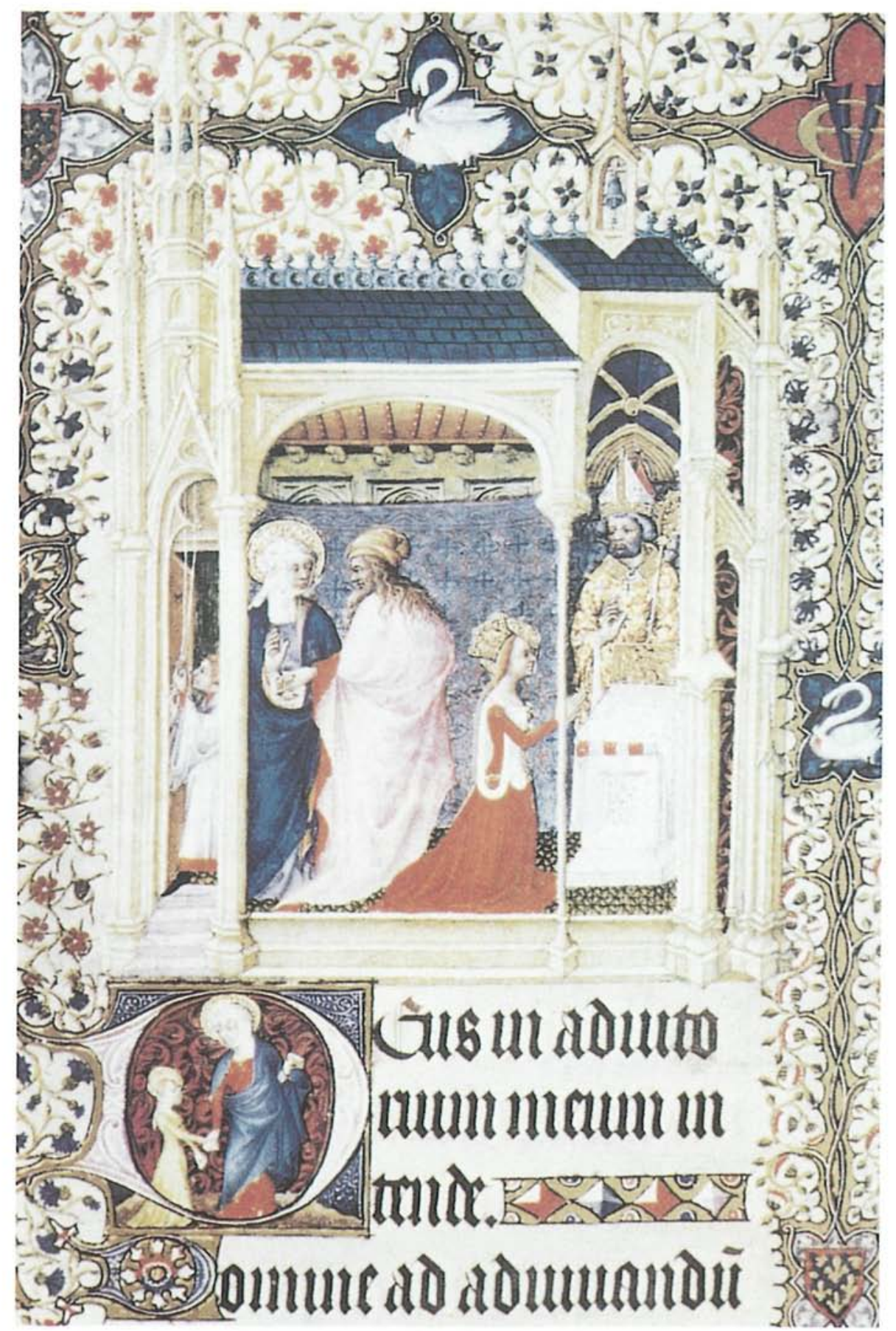

Fig. 8 


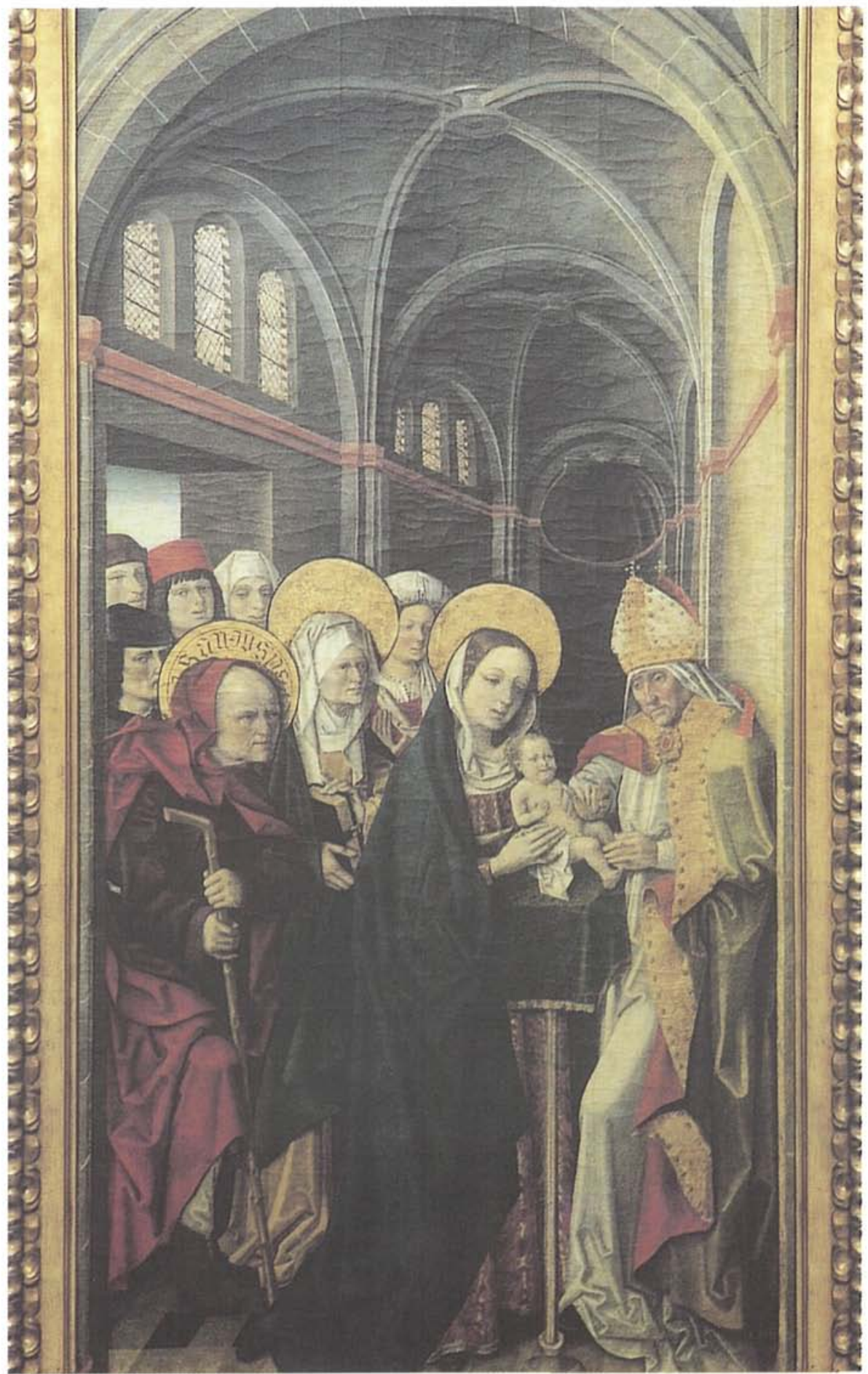

Fig. 9 


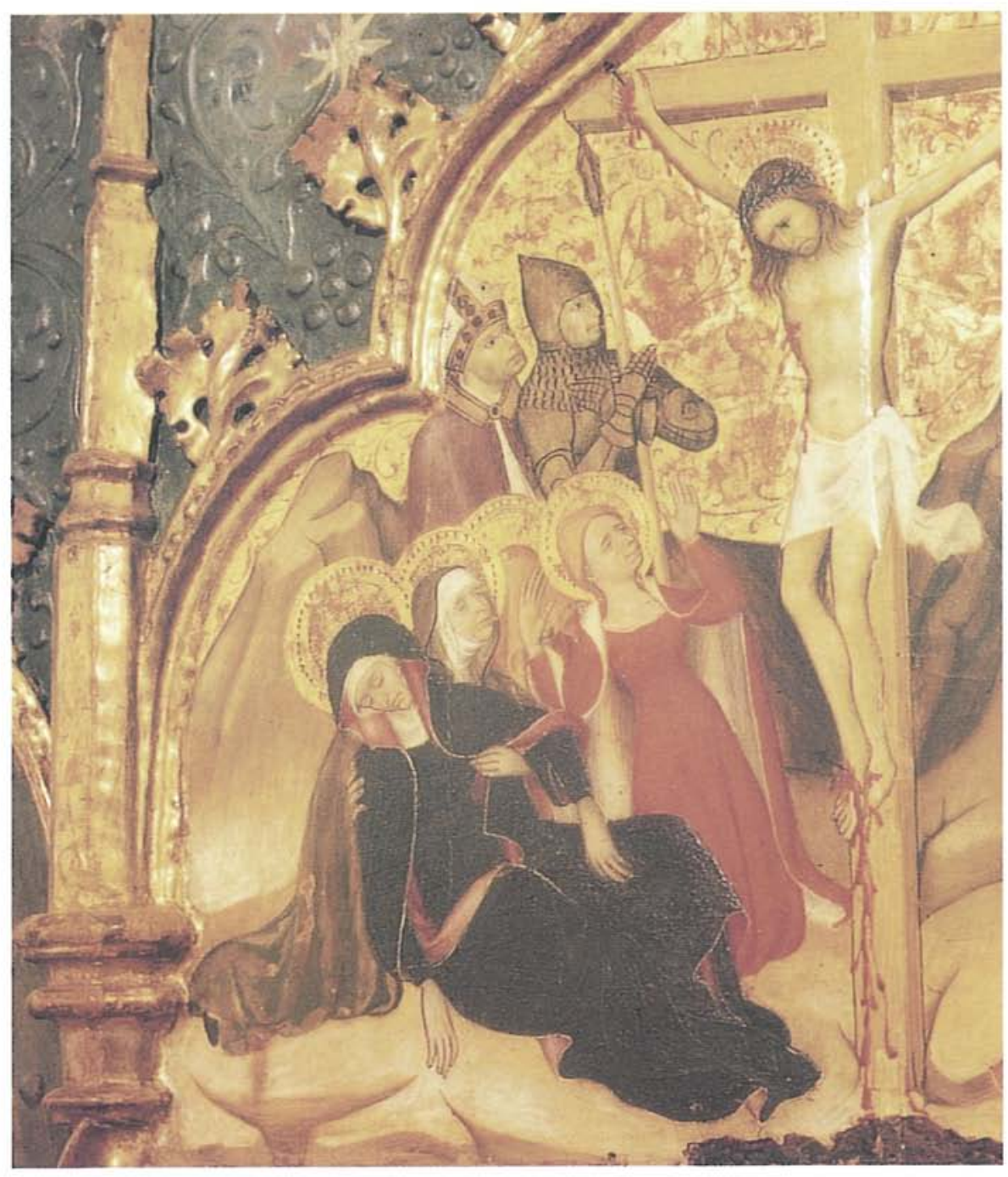

Fig. 10 


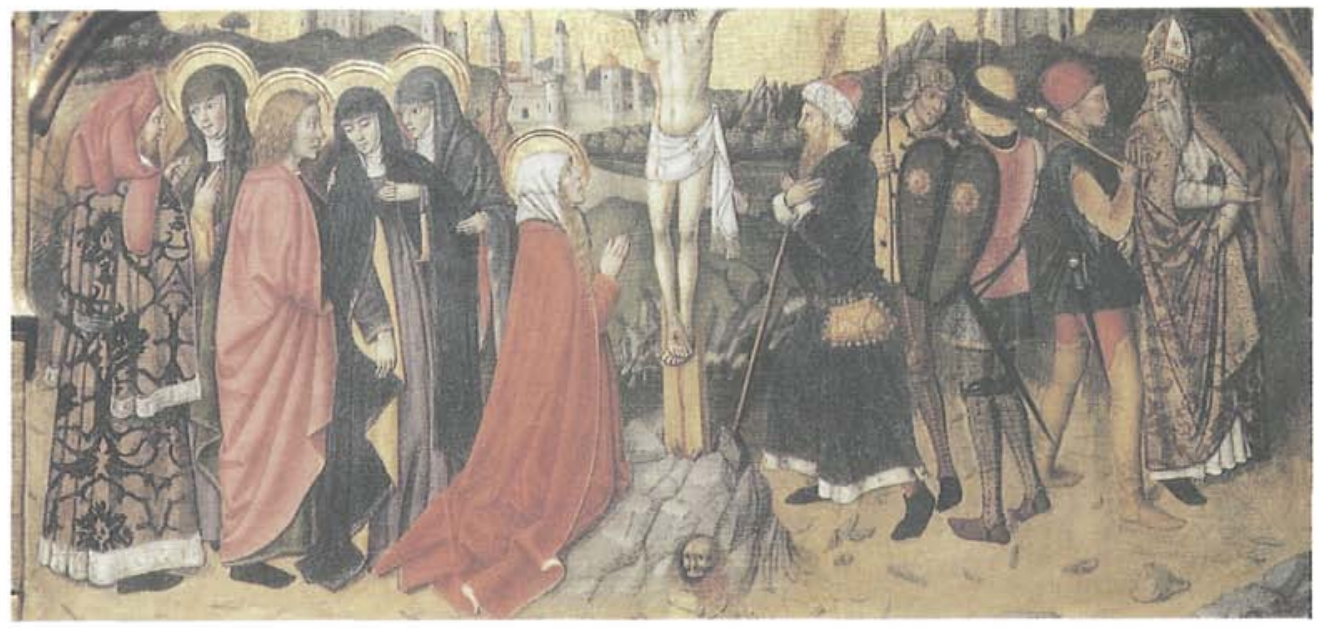

Fig. 11 


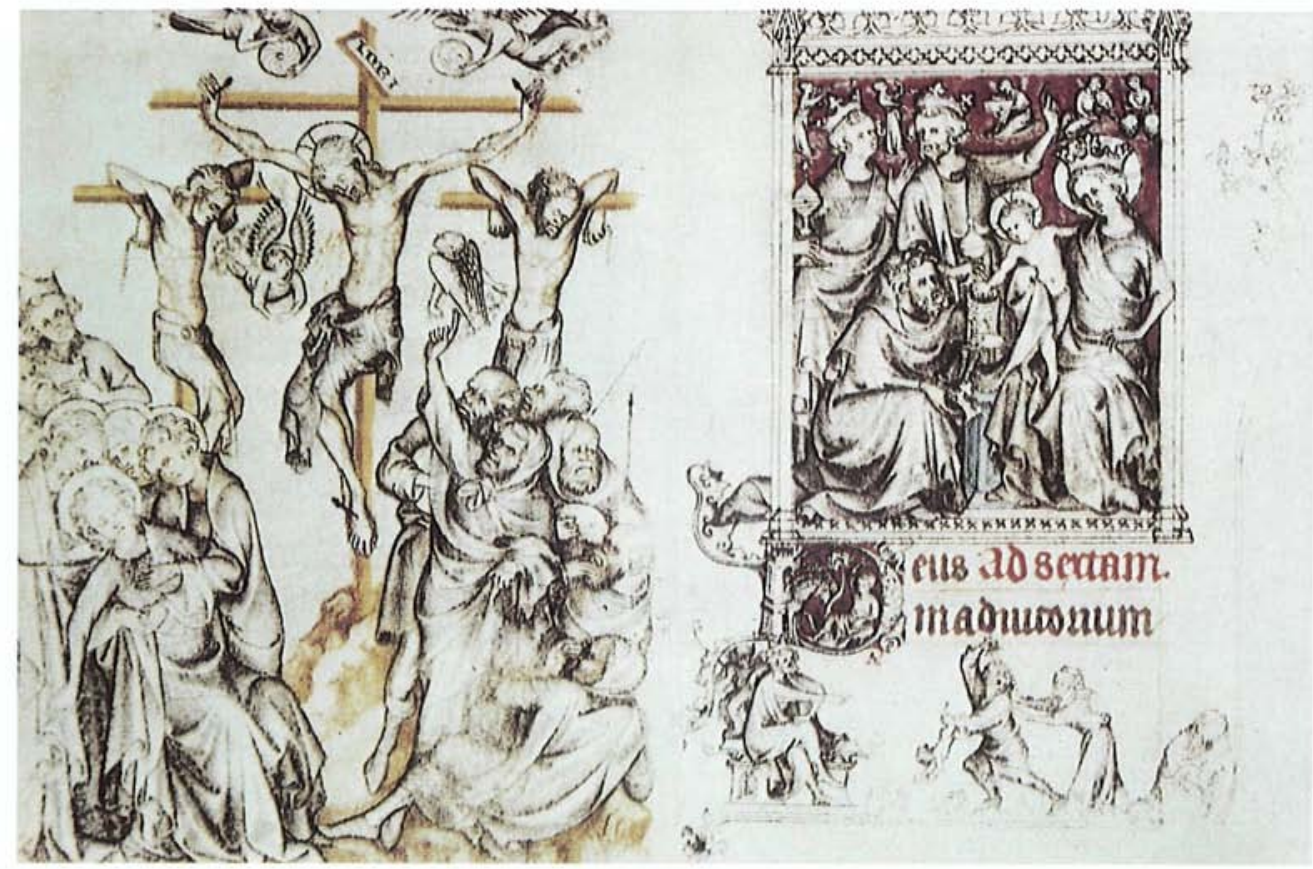

Fig. 12 


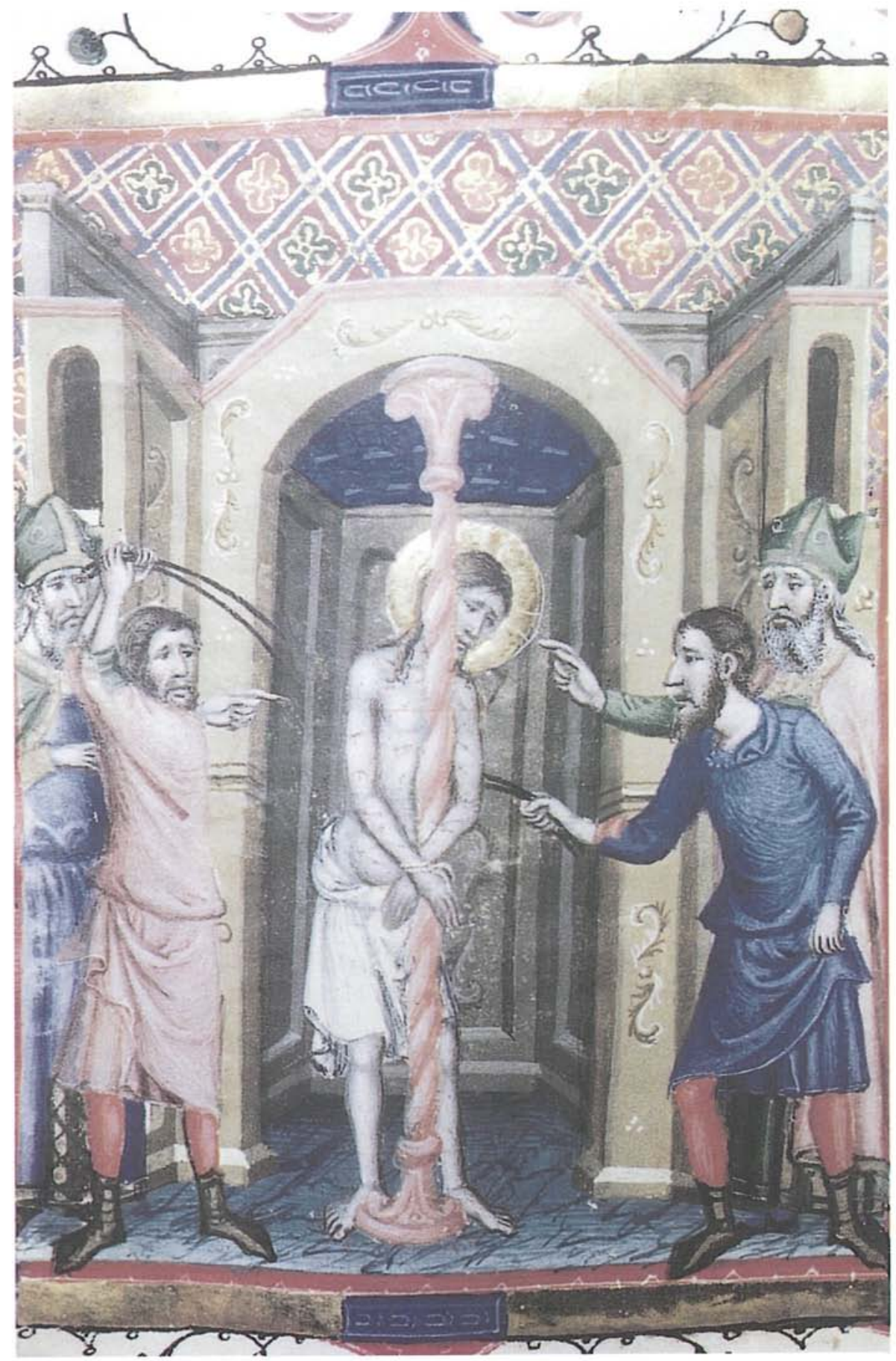

Fig. 13 


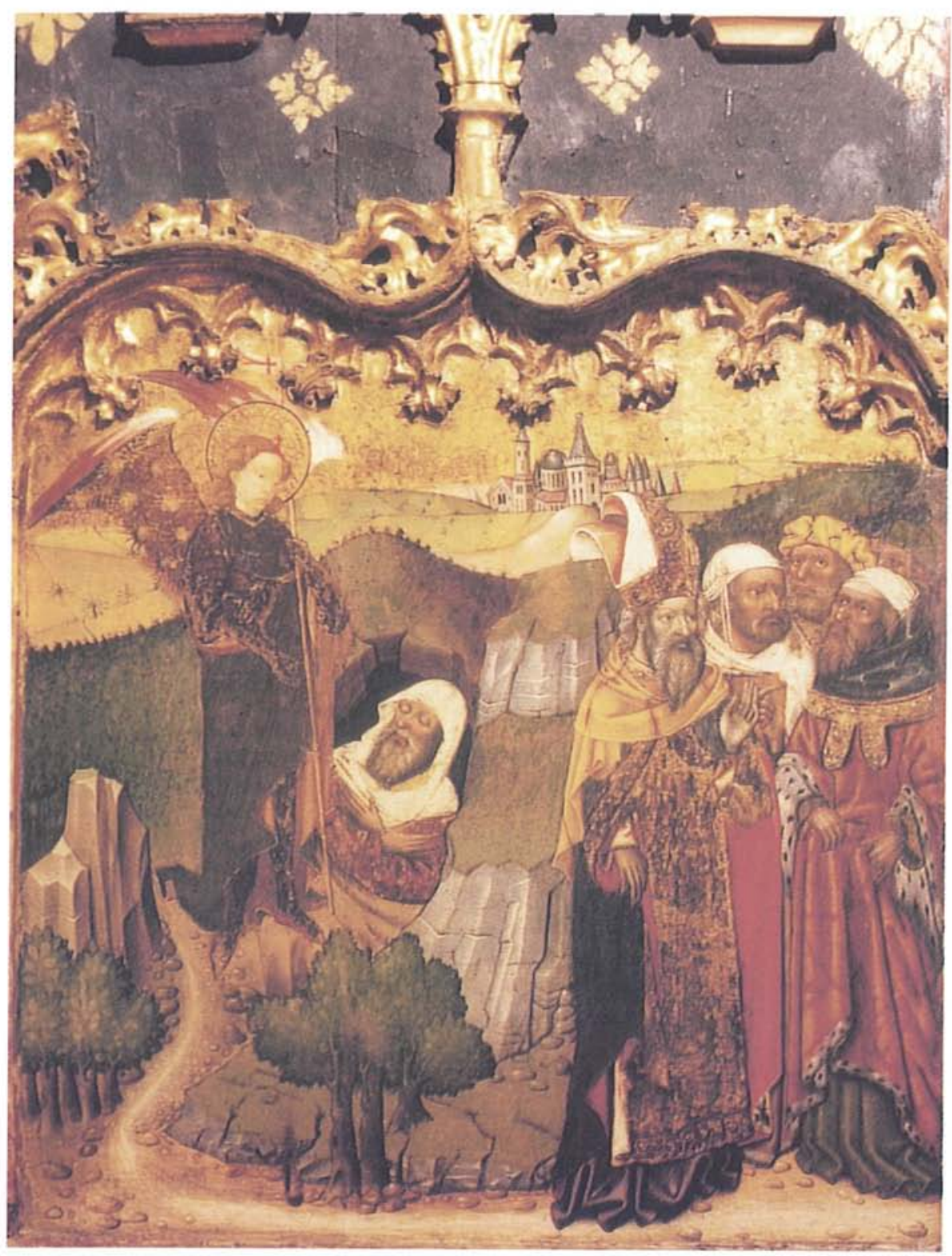

Fig. 14 